Volume 9. Nomor 2. Januari 2014
Pandecta
http://journal.unnes.ac.id/nju/index.php/pandecta

\title{
Pelestarian Situs Cagar Budaya Plawangan Rembang Perspektif Undang-Undang Cagar Budaya
}

\author{
Deky Akbar ${ }^{\bowtie}$
}

Fakultas Hukum Universitas Negeri Semarang, Semarang, Indonesia

\section{Info Artikel \\ Sejarah Artikel: \\ Diterima Oktober 2014 \\ Disetujui November 2014 \\ Dipublikasikan Desember 2014}

Keywords:

cultural reserve;

Plawangan;

Policy;

Rembang

\begin{abstract}
Abstrak
Undang-Undang Nomor 11 Tahun 2010 tentang Cagar Budaya, mengatur bahwa semua Cagar Budaya di Indonesia harus dilindungi dan Pemerintah harus melestarikan Cagar Budaya tersebut. Namun dalam kenyataannya di Situs Plawangan Kabupaten Rembang banyak benda-benda Cagar Budaya Situs Plawangan yang mengalami kerusakan dan benda-benda tersebut terabaikan, bahkan mengalami kehilangan. Penelitian ini bertujuan untuk menganalisis kebijakan pelestarian Situs Cagar Budaya Plawangan Kabupaten Rembang dilihat dari perspektif UndangUndang Nomor 11 Tahun 2010 Tentang Cagar Budaya dan menganalisis model yang relevan dalam Pelestarian Situs Cagar Budaya Plawangan Kabupaten Rembang. Penelitian ini menggunakan metode penelitian yuridis sosiologis. Hasil penelitian menunjukkan secara normatif pelestarian cagar budaya Plawangan dilakukan dalam rangka menjalankan amanat Undang-Undang Nomor 11 tahun 2010 tentang Cagar Budaya. Sementara secara sosiologis pelestarian situs cagar budaya disebabkan karena masyarakat tidak peduli dengan Situs Plawangan, sehingga banyak terjadi kerusakan di Situs Plawangan. Kemudian model pelestarian Situs Plawangan yang dilakukan oleh Dinas Kebudayaan, Pariwisata, Pemuda, dan Olahraga Kabupaten Rembang tidak optimal. Oleh sebab itu, maka masyarakat harus didorong kepedulian masyarakat terhadap pelestarian Situs Plawangan.
\end{abstract}

\begin{abstract}
Act No. 11 Year 2010 on Heritage, provides that all Heritage in Indonesia must be protected. But in reality in Plawangan Site Rembang many objects Heritage Site Plawangan damaged and neglected these objects, and even experience loss. This study aims to analyze the preservation of the heritage policy Plawangan Rembang viewed from the perspective of Law No. 11 Year 2010 on Heritage and analyze the relevant models in Preservation of Cultural Heritage Sites Plawangan Rembang. This study uses socio-juridical research. The results showed normatively, cultural heritage preservation Plawangan done in order to carry out the mandate of Act No. 11 Year 2010 on Heritage. While sociological preservation of cultural heritage sites because people do not care about the site Plawangan, so much damage in Plawangan. Later models of preservation site Plawangan conducted by the Department of Culture, Tourism, Youth, and Sports Rembang not optimal. Therefore, the public should be encouraged their awareness to conserv Plawangan site.
\end{abstract}




\section{Pendahuluan}

Kabupaten Rembang memiliki situs cagar budaya yang tersebar luas di Kabupaten Rembang. Salah satu diantara situs cagar budaya tersebut adalah Situs Plawangan yang dalam situs tersebut ada benda cagar budaya situs gerabah, situs penguburan mayat, dan aneka situs kerangka manusia. Situs plawangan yang terletak di Desa Plawangan, Kecamatan Kragan 35 km dari kota Rembang ke timur jurusan Surabaya. Luas 0,5 km (milik Dinas Purbakala), yang terdapat peninggalan sejarah berupa kerangka manusia yang diperkirakan hidup pada zaman logam awal (Paleomatalik). Pada tahun 1977 telah ditemukan kerangka manusia, cara penguburan mayan dengan sikap duduk dalam belanga, manik-manik, gerabah, benda-benda logam, keramik, dan lain-lain.

Berikut adalah diagram temuan gerabah, fragmen gerabah, manik-manik ekskavasi Plawangan:

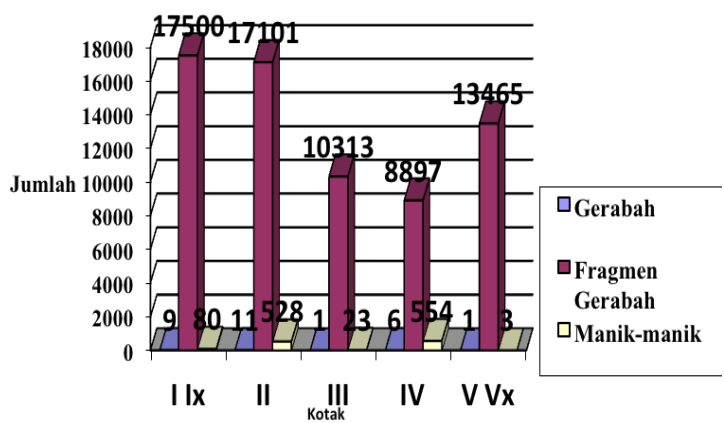

Gambar 1. Diagram Batang Temuan Gerabah, Fragmen Gerabah, Manik-manik Ekskavasi Plawangan.

Grafik di atas menunjukkan bahwa banyak temuan pada Situs Plawangan, jadi situs plawangan merupakan cagar budaya Kabupaten Rembang karena didalam temuan benda-benda bersejarah tersebut merupakan warisan budaya dan wajib untuk dilindungi dan diilestarikan agar situs plawangan tidak terjadi kerusakan pada situs plawangan.

Pada akhir tahun 2011 tepatnya bulan Desember, Junaidi sebagai juru kunci Situs Plawangan menegaskan bahwa terdapat kasus yang cukup menghebohkan warga Rembang dan sekitarnya, kasus itu tidak lain adalah peristiwa pengerusakan dan pencu- rian terhadap situs Plawangan di Kabupaten Rembang. Benda cagar budaya yang seharusnya dilestarikan, ternyata telah banyak mengalami kerusakan dan kehilangan akibat ulah tangan-tangan tidak bertanggung jawab. Hal ini tentu sangat ironis, mengingat Kabupaten Rembang selama ini dikenal sebagai daerah yang penuh dengan peninggalan purbakala, dengan keadaan tersebut, seharusnya mau tidak mau, Pemerintah berkolaborasi dengan masyarakat harus melestarikannya. Melestarikan dalam hal ini tentu bukan hanya melalui perawatan fisik, tetapi juga perawatan dengan aturan Undang-Undang yang dapat mengikat dan melindungi dengan erat peninggalan-peninggalan purbakala tersebut.

Hadirnya undang - undang baru yang mengatur peninggalan arkeologi dan purbakala di tengah-tengah masyarakat telah menjadi perbincangan yang cukup hangat. Undang-undang yang lama yakni UndangUndang RI Nomor 5 Tahun 1992 tentang Benda Cagar Budaya (UU-BCB) dengan Undang-Undang RI Nomor 11 Tahun 2010 tentang Cagar Budaya (UU-CB) telah mendoktrin pemikiran masyarakat dan pemerintah untuk lebih menguatkan dasar hukum dalam kaitannya pelestarian terhadap peninggalan cagar budaya dan purbakala. Bagaimanapun, bangsa yang besar adalah bangsa yang menghargai akan sejarahnya. Namun meskipun telah dilakukan revisi oleh pemerintah pusat terhadap Undang-Undang mengenai cagar budaya, hal tersebut tidak serta merta mampu diimplementasikan dengan baik oleh pemerintah daerah.

Berlakunya sistem Otonomi Daerah membuat Pemerintah Daerah memiliki kewenangan yang lebih untuk mentaati ataupun tidak melaksanakan Undang-Undang tersebut. Bila dalam kasus ini, Pemerintah Kabupaten Rembang peka, maka sudah sepantasnya dibuat PERDA (Peraturan Daerah) yang mampu menjadi landasan hukum yang kuat bagi perlindungan cagar budaya dan peninggalan purbakala. Namun sayangnya, sampai dengan skripsi ini saya buat, Peraturan Daerah tersebut belum juga lahir. Sejauh ini menurut sumber yang saya dapat, termasuk dari lingkup anggota dewan yang terhormat sebagai lembaga pemerintahan 
yang berwenang, pembuatan Perda ini masih sebatas wacana.

Seharusnya kasus pencurian dan pengerusakan Situs Plawangan menjadi momentum lahirnya Perda yang mengatur tentang pelestarian tersebut. Namun pada kenyataannya memang seperti inilah Indonesia, bila Hukum sudah ditunggangi oleh kepentingan elit politik yang tidak banyak diketahui oleh masyarakat awam, pada akhirnya masyarakat pula lah yang dirugikan atas kejadian ini. Padahal bila kita mau berkaca pada daerah lain di Indonesia seperti contoh Daerah Istimewa Yogyakarta sebagai Kota Budaya dan telah lama melahirkan Perda untuk melindungi peninggalan purbakala tersebut, dampak yang bakal dirasakan oleh masyarakat sekitar pun sangat menguntungkan. Karena peninggalan purbakala merupakan potensi wisata yang sangat menarik untuk para wisatawan, dan Pariwisata memiliki multiplayer effect yang sangat baik untuk masyarakat dan pemerintah.

Bila dengan adanya Perda, situs purbakala tersebut akan terjaga dengan baik, maka kunjungan wisatawan pun akan meningkat drastis, sehingga mampu menimbulkan dampak yang antara lain, meningkatkan PAD (Pendapatan Asli Daerah), meningkatkan ekonomi masyarakat sekitar lokasi peninggalan situs purbakala yang akhirnya menjadi obyek wisata yang potensial untuk dikunjungi oleh masyarakat, meningkatkan SDM warga sekitar, dan masih banyak lagi lainnya.

Foto Koleksi benda Situs Plawangan yang terabaikan menunjukkan bahwa peles-
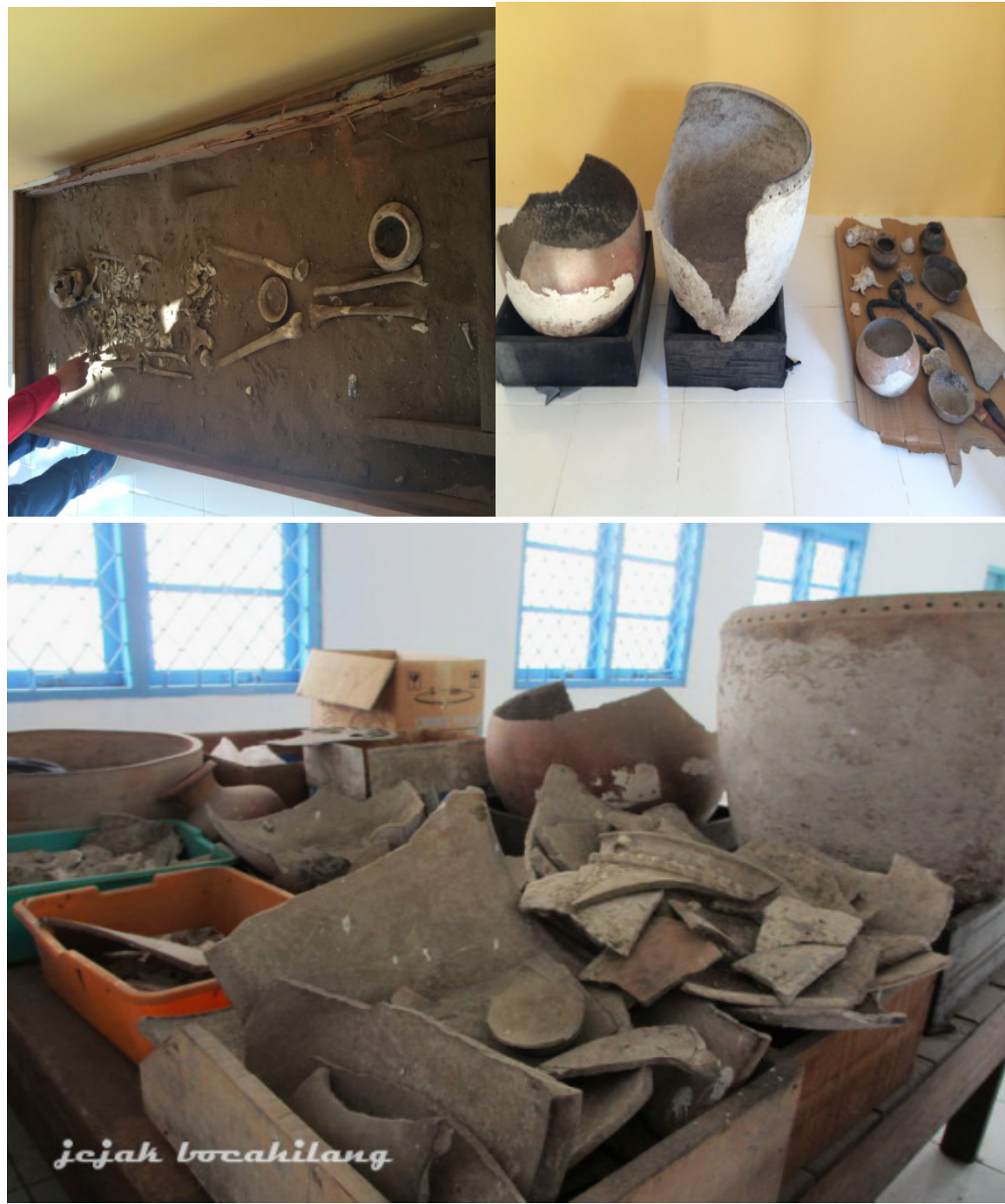

Gambar 2. Foto Koleksi benda Situs Plawangan yang terabaikan 
tarian dan perlindungan kurang, bahwa Perda yang seharusnya diciptakan oleh Pemkab akan lebih cocok bila mengadopsi UndangUndang No. 11 Tahun 2010 Tentang Cagar Budaya. Alasan yang mendasari tentu saja karena Undang-Undang yang baru tersebut telah mengalami revisi dan menyesuaikan dengan perkembangan global yang ada mengenai kepurbakalaan dibandingkan dengan Undang-Undang yang lama, yakni Undang - undang No. 5 Tahun 1992 tentang Benda Cagar Budaya.

Contoh model-model yang mungkin akan mampu bisa diterapkan dalam kaitannya untuk melestarikan situs purbakala antara lain adalah dengan cara memberikan kebebasan kepada setiap lapisan masyarakat yang ada untuk menjaga situs tersebut. Masalah yang terjadi selama ini adalah, UndangUndang maupun Perda yang ada diluar kasus ini masih terkesan membatasi peran masyarakat, sehingga warga yang mempunyai niatan mulia untuk ikut membantu pelestarian ataupun peran pemerintah merasa tidak memiliki kewenangan untuk melakukan tindakan apapun karena telah dibatasi oleh UndangUndang yang telah berlaku.

Bila model perda seperti ini benarbenar dilaksanakan secara baik dengan tidak membatasi siapapun untuk melaksanakan pelestarian, maka saya berani menjamin bahwa proses penjagaan dan perawatan peninggalan purbakala yang ada di Kabupaten Rembang akan lebih berjalan maksimal dan efektif, karena masyarakat juga diberi kebebasan untuk ikut berperan dalam menjaganya. Tetapi sebaliknya, bila dalam Perda nanti masih terdapat aturan yang bersifat memberikan batasan, atau bahkan hanya pemerintah saja yang diberikan wewenang untuk melakukan pelestarian, maka sudah barang tentu proses pelestarian pun tidak akan berjalan dengan efektif, karena tugas Pemerintah Kabupaten sendiri tidak hanya mengurusi tentang kepurbakalaan, tetapi juga masih banyak masalah lain yang tidak kalah pelik, sehingga tidak ada salahnya bila pemerintah melibatkan masyarakat dalam rangka melindungi peninggalan Cagar Budaya dan Purbakala yang ada di Kabupaten Rembang.

Penelitian ini bertujuan untuk menga- nalisis kebijakan pemerintah daerah Kabupaten Rembang dalam Pelestarian Situs Cagar Budaya Plawangan Kabupaten Rembang berdasarkan ketentuan Undang-Undang Nomor 11 tahun 2010 tentang Cagar Budaya. Selanjutnya, akan dianalisis juga mengenai model kebijakan yang relevan dalam pelestarian Situs Cagar Budaya Plawangan Kabupaten Rembang.

\section{Metode Penelitian}

Metode penelitian yang akan penulis gunakan dengan pendekatan yuridissosiologis, yang mana pendekatan tersebut disamping melihat secara langsung ketentuan Undang-Undang dan Peraturan Daerah yang mengatur masalah Benda-Benda Cagar Budaya juga melihat secara langsung yang terjadi di lapangan (Soekanto, 1982:32; Waluyo, 2002:77). Analisis data dilakukan dengan mengorganisasikan data, memilah-milahnya menjadi satuan yang dapat dikelola, mengsintesiskannya, mencari dan menemukan pola, kemudian di bahas untuk menjawab permasalahan penelitian yang kemudian di tarik kesimpulan dari seluruh hasil dan pembahasan (Moleong, 2013 : 248; Miles dan Huberman, 2007: 20).

\section{Hasil Penelitian dan Pembahasan}

\section{a. Profil Situs Cagar Budaya Plawangan Kabupaten Rembang}

Kabupaten Rembang memiliki letak yang strategis, tidak heran jika mempunyai situs Cagar Budaya yang tersebar luas di Kabupaten Rembang, salah satu diantara situs cagar budaya tersebut adalah Situs Plawangan yang dalam situs tersebut ada benda cagar budaya situs gerabah, situs penguburan mayat, dan aneka situs kerangka manusia. Situs plawangan yang terletak di Desa Plawangan, Kecamatan Kragan 35 km dari kota Rembang ke timur jurusan Surabaya. Luas 0,5 km (milik Dinas Purbakala), yang terdapat peninggalan sejarah berupa kerangka manusia yang diperkirakan hidup pada zaman logam awal (Paleomatalik). Pada tahun 1977 telah ditemukan kerangka manusia, cara penguburan 
mayan dengan sikap duduk dalam belanga, manik-manik, gerabah, benda-benda logam, keramik.

Hal tersebut di akui juga oleh Junaidi penjaga dan sekaligus mengikuti langsung penggalian Situs Plawangan (Wawancara, 16/5/2014). Situs Plawangan ditemukan pada tahun 1977 yang dilakukan penggalian odari tim ahli dan di damping oleh Dinas Kebudayaan, Pariwisata, Pemuda, dan Olahraga. Pada waktu itu masyarakat Plawangan membuat balai desa gotong royong dan pada waktu itu seorang menemukan benda barang kuno, pada waktu itu masyarakat melaporkan ke Kepala Desa kemudian Kepala Desa melanjutkan laporan ke dinas Dinas Kebudayaan, Pariwisata, Pemuda, dan Olahraga. Dinas Kebudayaan, Pariwisata, Pemuda, dan Olahraga melakukan pengecekan ke tempat penemuan Situs tersebut. Berhubung Dinas Kebudayaan, Pariwisata, Pemuda, dan Olahraga belum mempunyai tim ahli untuk melakukan penggalian kemudian dinas bekerja sama dengan BPCB untuk melakukan penggalian. Pada tahun 1978 Dinas Kebudayaan, Pariwisata, Pemuda, dan Olahraga, BPCB, dan tim ahli penggalian melakukan pemberhentian penggalian dan sisa penggalian ditutup kembali dengan tanah lagi, dan kemudian tanah bekas banguna tersebut di bangun rumah sakit. Pada tahun 1981 saya diangkat sebagai penjaga Situs Plawangan, kemudian dinas membangun gedung arkeologi untuk menjadikan satu benda-benda Situs Plawangan agar tidak mengalami kerusakan.

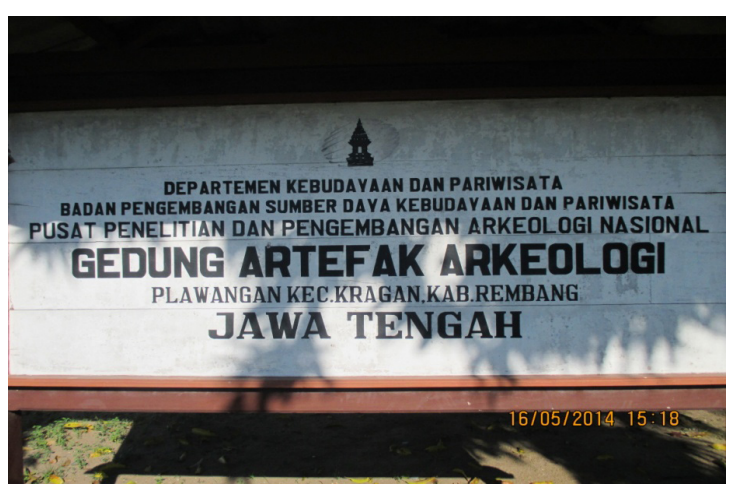

Gambar 3. Plang Gedung Artefak Arkeologi Situs Plawangan.

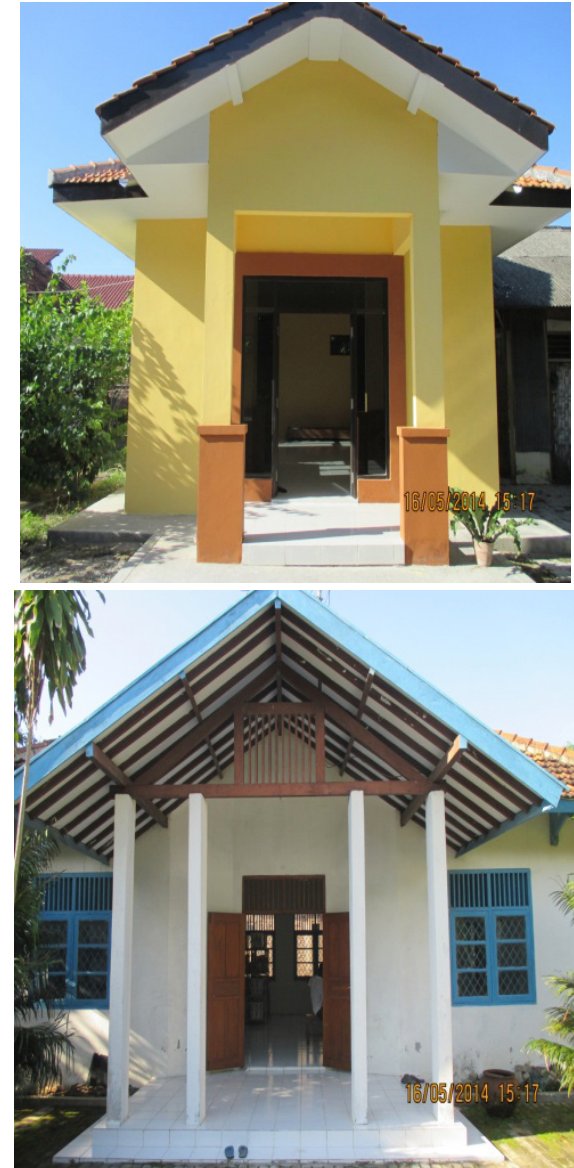

Gambar 4. Gedung Penyimpanan Benda Cagar Budaya Situs Plawangan.

Situs Plawangan yang terletak di Desa Plawangan, Kecamatan Kragan, Kabupaten Rembang dan yang terletak yang sekarang di buatkan tempat Gedung Artefak Arkeolog untuk menyimpan hasil penggalian pada Tahun 1977 dan dijadikan satu pada Gedung Artefak Arkeolog tersebut. Dalam Tahun 1977 tersebut telah banyak ditemukan hasil penggalian seperti kerangka manusia, cara penguburan mayan dengan sikap duduk dalam belanga, manik-manik, gerabah, bendabenda logam, keramik. Dari penemuan yang begitu banyak tersebut kemudian Kabupaten Rembang menetapkan Situs Plawangan tersebut sebagai Cagar Budaya dimana keberadaannya sangat penting dan sudah memenuhi syarat perundang-undangan yang berlaku pada saat itu. 


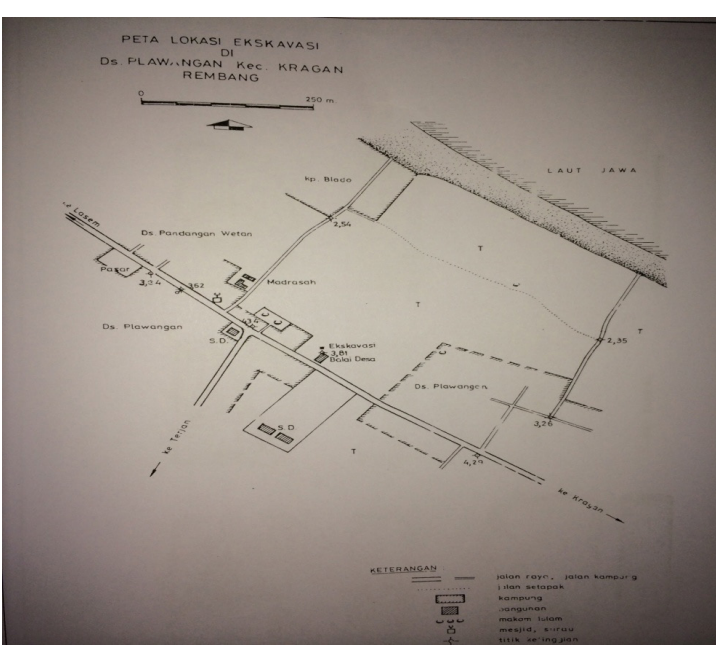

Gambar 5. Peta Lokasi Ekskavasi di Ds. Plawangan, Kec. Kragan, Rembang

Gambar Peta Lokasi diatas menjelaskan bahwa ekskavasi dilakukan di sekitar Desa Plawangan, dan dalam melakukan ekskavasi tersebut telah muncul data yang menjelaskan banyaknya benda - benda Cagar Budaya yang ditemukan, berikut adalah grafik yang diambil dari hasil laporan penelitian Situs Terjan dan Situs Plawangan Jawa Tengah tahap I dan II :

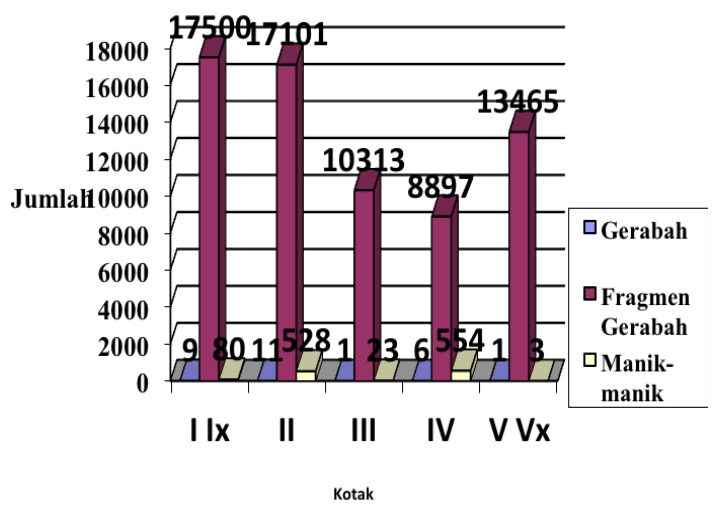

Sumber: Sukendar dan Awe, 1982.

Gambar 6. Diagram Batang Temuan Gerabah, Fragmen Gerabah, Manik-manik Ekskavasi Plawangan

Data di atas menunujukkan bahwa Situs Plawangan sangatlah penting keberadaanya, mengingat dengan temuan - temuan benda Cagar Budaya banyak ditemukan, dan banyak benda - benda Cagar Budaya yang masih belum digali dari bekas penggaliannya tersebut. Oleh karenanya, Situs Plawangan sangat memprihatinkan dalam keadaannya, keadaan Situs Plawangan di dalam pengelolaannya sangatlah kurang, mengingat program kerja yang dilaksanakan belum ada dan hanya penjaga Situs Plawangan dengan menjaga dan melestarikan dengan seadanya dan peralatan yang seadanya. Dalam hasil kerja tentu saja kurang baik mengingat dalam program kerja tidak ada. Maka diperlukan peran pemerintah dalam pembentukan program kerja Situs Plawangan tersebut.

\section{b. tPelestarian Situs Cagar Budaya Plawangan}

Situs Plawangan Kabupaten Rembang merupakan Cagar Budaya Kabuten Rembang yang dilindungi oleh Perundang-undangan yang ada di Indonesia. Berdasarkan UUD 1945 khususnya Pasal 32 menyebutkan bahwa Negara memajukan kebudayaan nasional Indonesia di tengah peradaban dunia dengan menjamin kebebasan masyarakat dalam memelihara dan mengembangkan nilai-nilai budaya. Negara menghormati dan memelihara bahasa daerah sebagai kekayaan budaya nasional (Wirastari dan Suprihardjo, 2012:2).

Keberadaan benda Cagar Budaya di Situs Plawanagan Kabupaten Rembang masih rawan dari kerusakan dan kemusnahan, baik yang disebabkan oleh faktor alam maupun ulah manusia. Untuk itu perlu diungkap bagaimana perlindungan hukumnya dan apakah peraturan perundang - undangan yang ada sudah memadai dalam upaya memberikan perlindungan terhadap benda-benda tersebut. Kurangnya apresiasi terhadap benda cagar budaya menjadi salah satu faktor semakin tingginya ancaman, seperti perusakan, dan pemalsuan terhadap benda cagar budaya yang ada di Kabupaten Rembang kondisi tersebut diperparah lagi dengan kurangnya sosialisasi tentang hukum perlindungan terhadap benda cagar budaya itu sendiri serta keadaan ekonomi masyarakat yang masih minim. Urgensi Normatif sangatlah penting dalam melakukan pelestarian Situs Cagar Budaya Plawangan dimana Cagar Budaya sangatlah penting bagi bangsa kita, dalam peraturan perundang - undangan saat ini 
adala Undang - Undang Republik Indonesia Nomor 11 Tahun 2010 tentang Cagar Budaya dan Perda Jawa Tengah Nomor 10 Tahun 2013 tentang Pelestarian dan Pengolahan Cagar Budaya Jawa Tengah.

Peraturan per-Undang - Undangan yang mengatur Cagar Budaya memang benar kalau Kabupaten Rembang belum mempunyai Perda yang mengatur Cagar Budaya, dalam hal ini seharusnya Kabupaten Rembang seharusnya harus sudah mempunyai Perda yang mengatur tentang Cagar Budaya mengingat bahwa Kabupaten Rembang mempunyai cukup banyak Cagar Budaya yang harus dilindungi keberadaannya dan di lestarikan benda - benda Cagar Budaya tersebut. Hal tersebut di akui juga oleh Sunarto Kepala Dinas Kebudayaan, Pariwisata, Pemuda, dan Olahraga Kabupaten Rembang (Wawancara, 6/6/2014).

Kabupaten Rembang memang belum mempunyai Perda yang mengatur tentang Cagar Budaya, tetapi untuk rancangan Perda kita sudah ada dan itu juga tinggal menunggu putusan dari DPR Kabupaten Rembang. Saya sebagai Kepala Dinas Kebudayaan, Pariwisata, Pemuda dan Olahraga selalu terus mendorong supaya cepat disahkan, mengingat Kabupaten Rembang sabgat membutuhkan Perda tersebut untuk melindungi dan melestarikan Cagar Budaya di Kabupaten Rembang.

Situs Plawangan adalah salah satu Cagar Budaya Kabupaten Rembang yang harus dan mendesak dalam pembuatan Perda tentang Cagar Budaya tersebut agar bendabenda Cagar Budaya Situs Plawangan dan terlindungi. Karena Perda Kabupaten Rembang tentang Cagar Budaya belum ada maka Undang-Undang Republik Indonesia Nomor 11 Tahun 2010 tentang Cagar Budaya sangatlah berperan penting untuk melindungi dan melestarikan Situs Cagar Budaya Plawangan yang benda - benda Cagar Budaya situs tersebut kebanyakan dijumpai dalam kerusakan dan kurang terurus.

Mengingat bahwa Cagar Budaya sangatlah penting keberadaannya bagi Bangsa Indonesia maka peraturan yang mengenai Cagar Budaya sangatlah penting khususnya Undang - Undang Republik Indonesia No- mor 11 Tahun 2010 tentang Cagar Budaya mengingat juga Kabupaten Rembang belum mempunyai Perda tentang Cagar Budaya.

Selain alasan normatif, urgensi sosisologis juga sangat dibutuhkan mengingat masyarakat juga berperan penting dalam pelestarian Situs Cagar Budaya Plawangan. Peran serta tokoh masyarakat didalam mengupayakan pelestarian cagar budaya merupakan hal yang harus dilakukan, mengingat cagar budaya merupakan titisan peningalan nenek moyang kepada kita yang tentunya harus dijaga, dirawat, agar tidak punah. Cagar budaya merupakan asset yang berharga dan mempunyai nilai sosial yang tinggi di masa sekarang. Oleh sebab itu cagar budaya harus dilestariakan dan tetap dipertahankan, untuk itu masyarakat juga berperan penting dalam melakukan pelestarian Situs Plawangan karena lingkungan sekitar juga sangat mempengaruhi dalam pelestarian Situs Plawangan tersebut. Pelestarian kawasan cagar budaya adalah segenap proses konservasi, interpretasi, dan manajemen terhadap suatu kawasan agar makna kultural yang terkandung dapat terpelihara dengan baik. Dalam sebuah pelestarian kawasan cagar budaya perlu disediakan kesempatan kepada masyarakat yang bertanggung jawab kultural terhadap kawasan tersebut untuk ikut berpartisipasi dalam proses pelestarian. Kriteria pelestarian dapat diukur dari kekhasan kawasan, kesejarahan kawasan, keistimewaan kawasan, dan partisipasi masyarakat. Hal tersebut di akui juga oleh Sunarto Kepala Dinas Kebudayaan, Pariwisata, Pemuda, dan Olahraga Kabupaten Rembang (Wawancara, 6/6/ 2014).

Situs Plawangan masih banyak yang belum digali benda-benda Cagar Budaya Situs Plawangan, dan belum dilakukan penggalian lagi selama ini. Saya sebagai Kepala dinas juga sudah bekerja sama Kepala Desa dan masyarakat jika ada penemuan lagi dari benda tersebut harap melaporkan ke dinas, tapi selam ini keadaan masyarakat tidak mau tahu dengan hal tersebut, Situs Plawangan sangatlah penting untuk pendidikan dan generasi penerus. Hal tersebut di perkuat dengan pernyataan oleh Edi Winarno Ketua LSM MSI (Masyarakat Sejarawan Indonesia) Kabu- 
paten Rembang (Wawancara, 9/6/ 2014).

Masyarakat Situs Plawangan kurang jelas bagaimana pertanggung jawaban jika terjadi kerusakan benda-benda Cagar Budaya Situs Plawangan, melihat dengan sejarah panjang Situs Plawangan mengingat Situs ter- sebut adalah Situs yang sangat penting dan berguna bagi masyarakat juga, tetapi kondisi masyrakat sekitar Situs Plawangan kurang mengetahui Situs Plawangan tersebut dan kurang peduli dengan keadaan Situs Plawangan tersebut. Kemudian kami sebagai LSM

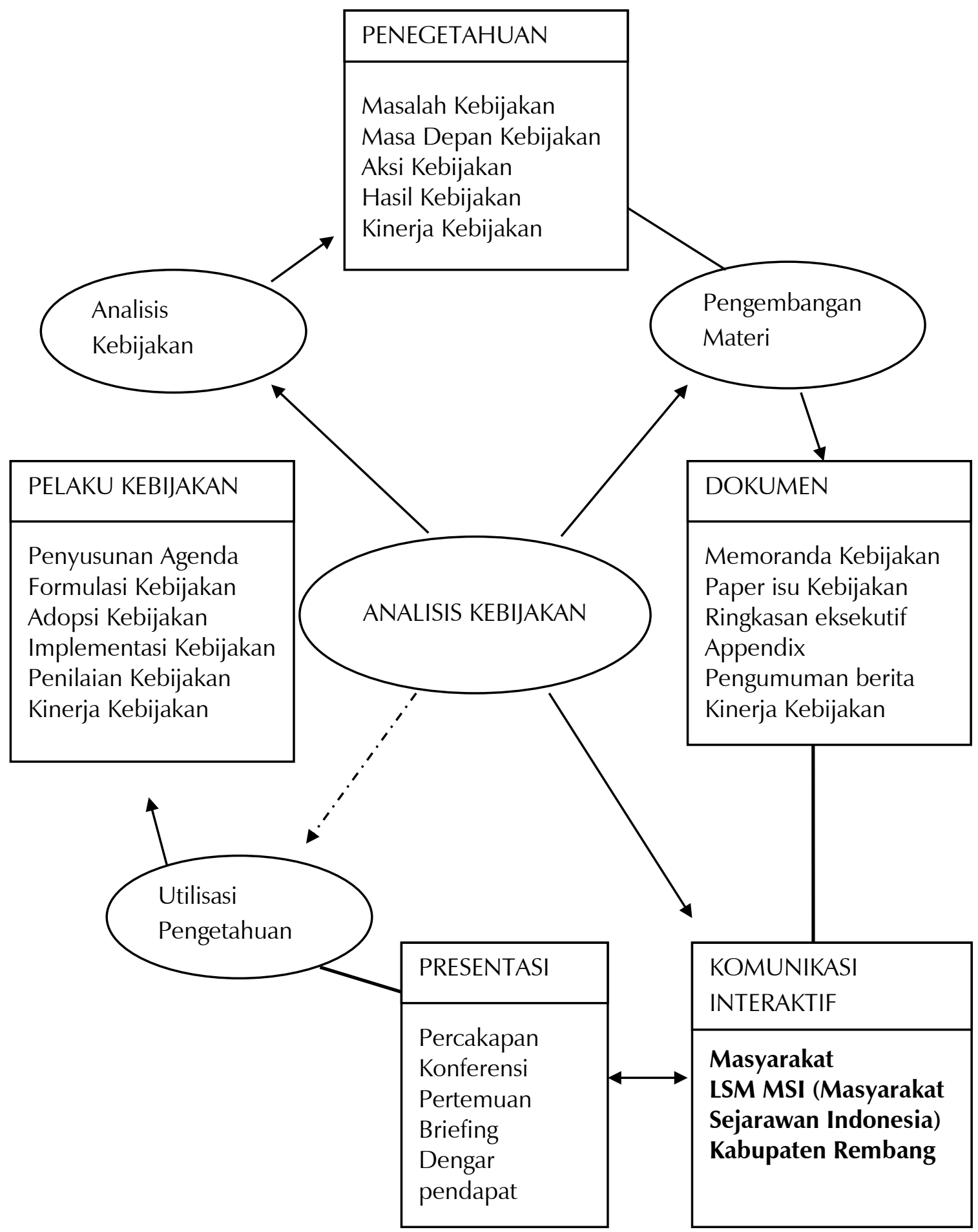

Bagan 1. Proses Komunikasi Kebijakan (Dunn, 2003 : 31) 
Masyarakat Sejarawan Indonesia Kabupaten Rembang, kami berusaha mesosialisasikan terus kepada masyarakat bahwa benda Cagar Budaya sangatlah penting kita lestarikan dan kita jaga yang khususnya adalah Situs Plawangan tersebut yang butuh perhatian serius dan peran masyarakat sekitar Situs Plawangan tersebut.

Pernyataan tersebut juga diakui oleh masyarakat sekitar Wawancara dengan masyarakat yaitu dengan fajar Setya Wicaksana, Mahmudi, dan Abdul Fatah yang berkesimpulan dari pernyataannya adalah (Wawancara, 16/5/2014): "Masyarakat disini belum menyadari bahwa Situs Plawangan adalah sangat penting keberadaannya, dan sangatlah dibutuhkan peran dari masyarakat untuk bersama-sama menjaga dan melestarikannya, tetapi kondisi masyarakat sekitar Situs Plawangan saya akui memang kurang peduli".

Data tersebut menunjukkan, ternyata peran masyarakat didalam pelestarian Situs Cagar Budaya Plawangan sangatlah diperlukan, tentu saja juga akan dibantu oleh LSM yang terkait dalam hal ini, yang dalam hal ibni masih aktif adal LSM Masyarakat Sejarawan Indonesia (MSI), maka masyarakat harus lebih memperhatikan Situs Plawangan mengingat dengan keadaan Situs Plawangan saat ini keadaannya memprihatinkan.

Merujuk pada teori William N. Dunn dalam proses komunikasi kebijakan sangat penting bagi masyarakat dan LSM yang terkait dalam pelestarian Situs Plawangan, proses komunikasi kebijakan tersebut adalah sebagai 1 .

Proses Kebijakan komunikasi diatas sangat penting mengingat masyarakat juga mebutuhkan komunikasi interaktif dari sebuah kebijakan tersebut, dan akhirnya nanti pelestarian tersebut juga mebutuhkan peran dari masyarakat sekitar dan manfaat dari Situs Plawangan tersebut juga nanti berguna juga untuk masyarakat. Merujuk pada Undang Undang Republik Indonesia Nomor 11 Tahun 2010 tentang Cagar Budaya pasal Pasal 55 yang berbunyi "Setiap orang dilarang dengan sengaja mencegah, menghalang-halangi, atau menggagalkan upaya Pelestarian Cagar Budaya", dan di perkuat lagi pasal Pasal 57
"Setiap orang berhak melakukan Penyelamatan Cagar Budaya yang dimiliki atau yang dikuasainya dalam keadaan darurat atau yang memaksa untuk dilakukan tindakan penyelamatan". Pasal 58 ayat (1) juga menjelaskan "Penyelamatan Cagar Budaya dilakukan untuk : a. mencegah kerusakan karena faktor manusia dan/atau alam yang mengakibatkan berubahnya keaslian dan nilai-nilai yang menyertainya; dan b. mencegah pemindahan dan beralihnya pemilikan dan/atau penguasaan Cagar Budaya yang bertentangan dengan ketentuan peraturan perundang-undangan".

Peraturan diatas juga di perkuat dengan adanya Perda Provinsi Jawa Tengah Nomor 10 Tahun 2013 Tentang Pelestarian dan Pengelolaan Cagar Budaya Jawa Tengah, seperti dalam ketentuan Pasal 9 yang menyebutkan bahwa setiap orang wajib melakukan Penyelamatan Cagar Budaya yang dimiliki atau yang dikuasainya dalam keadaan darurat dan/atau yang memaksa untukdilakukan tindakan penyelamatan. Selanjutnya, dalam Pasal 10 dijelaskan bahwa Penyelamatan Cagar Budaya dilakukan untuk:

a. Penyelamatan tersebut dilakukan dalam keadaan darurat dan keadaan biasa. Peraturan diatas sudah sangat jelas mengatur bahwa masyarakat juga berperan penting dalam hal pelestarian Situs Cagar Budaya dalam hal ini adalah Situs Plawangan, mengingat Situs Plawangan memerlukan perhatian serius dalam pelestariannya karena masyarakat sekitar Situs Plawangan acuh dengan keadaan Situs Plawangan yang perlu diketahui keadaannya benda - benda Cagar Budaya Situs Plawangan sangatlah memprihatinkan, dari keadaan lingkungan sekitar Situs Plawangan kurang mendukung, mengingat bahwa tempat Situs Plawangan kurang diketahui masyarakat sekitar dan informasi tentang Situs Plawangan kurang diketahui oleh masyarakat sekitar. Karena kurang menegtahuinya keaadaan Situs Plawangan, masyarakat sekitar sangat kurang peduli dengan Situs Plawangan ini. 
Merujuk pada teori Soekmono (2012) Perubahan kebudayaan diakibatkan dua macam sebab, ialah: sebab yang berasal dari dalam, yaitu dari masyarakat pendukungnya sendiri, dan sebab yang berasal dari luar, yaitu dari luar lingkungan masyarakat.

Berdasarkan teori tersebut masyarakat sangatlah berperan dalam kebudayaan, yang dimaksud kebudayaan tersebut adalah Cagar Budaya yang menjadi bagian dari masyarakat, jika masyrakat disini sangat peduli dengan Cagar Budaya Situs Plawangan maka sangat mungkin untuk mencegah kerusakan yang berkelanjutan saat ini, dan jika masyarakat sangat peduli dengan Cagara Budaya Situs Plawangan maka pengaruh negatif dari luar lingkungan juga akan tidak masuk karena kepedulian masyarakat dengan Cagar Budaya sangat peduli. Tetapi berbalik dengan keadaan tersebut malah masyarakat sekitar Situs Plawangan tidak peduli dengan keadaan Cagar Budaya Situs Plawangan yang saat ini banyak benda - benda yang mengalami kerusakan.

Kebudayaan mengandung keseluruhan pengertian nilai sosial, norma sosial, ilmu pengetahuan serta keseluruhan strukturstruktur sosial, religious, dan lain-lain, tambahan lagi segala pernayataan intelektual dan artistik yang menjadi ciri khas suatu msyarakat. Kebudayaan juga menjadi suatu sistem konsep yang diwariskan yang terungkap dalam bentuk-bentuk simbolik yang dengannya manusia berkomunikasi, melestarikan, dan memperkembangkan pengetahuan mereka tentang kehidupan dan sikap-sikap terhadap kehidupan. Oleh karenanya kebudayaan merupakan pola tingkahlaku yang dipelajari dan disampaikan dari suatu generasi ke generasi berikutnya. Paling tidak ada tiga proses belajar kebudayaan yang penting, yaitu dalam kaitannya dengan manusia sebagai makhluk hidup dan sebagai suatu sistem sosial (Antonius, 2013:893; Koentjaraningrat, 2002:74; Soekmono, 2012:16).

Situs purbakala Plawangan di Desa Plawangan, Kecamatan Kragan, Rembang, ditemukan secara tidak sengaja oleh sebuah tim dari Balai Arkeologi Jakarta. Awalnya, tahun 1976 tim di bawah pimpinan Prof Soejono itu tengah melakukan penggalian di sekitar situs batu megalitikum di Desa Terjan, $5 \mathrm{~km}$ selatan Desa Plawangan. Selama beberapa bulan penggalian, tim tidak menemukan tanda-tanda adanya fosil yang dicari. Pada 1977, seorang warga Desa Plawangan isengiseng datang ke Terjan menunjukkan sebuah tulang kepada anggota tim. "Ternyata tulang itu yang dicari oleh tim dari Balai Arkeologi. Kemudian dari 1977 hingga 1983 dilakukan penggalian terus-menerus hingga menemukan ribuan fosil dan benda purbakala," tutur Junaedi, juru kunci situs Plawangan yang juga ikut membantu penggalian sejak 1977. Koleksi penemuan benda Cagar Budaya Situs Plawangan memang sangat bermacam-macam dalam jenis penemuannya dan sudah seharusnya ini mendapat perhatian serius dari Pemerintah Kabupaten Rembang.

Tahun 1985 di Desa Plawangan di pesisir utara Jawa Tengah, Kabupaten Rembang tiba-tiba saja gempar dan ramai menjadi pembicaraan orang karena di desa kecil yang mayoritas penduduknya petani ikan atau nelayan tersebut ditemukan dua rangka manusia dikubur dalam nekara perunggu. Nekara adalah semacam bejana atau "dandang" perunggu yang bentuknya terbalik. Pada umumnya nekara mempunyai berbagai macam ornamen atau hiasan, seperti bentuk bintang, binatang (burung, kodok, kadal, ikan dan sebagainya) serta bentuk-bentuk manusia atau kodok yang sudah distilir. Nekara merupakan produk budaya prasejarah yang berkembang pada masa perundagian (paleometalik) dan berfungsi sebagai sarana dalam upacara keagamaan. Pada umumnya nekara didapatkan dari hasil "temuan lepas" dan penyebarannya hampir meliputi seluruh kepulauan Indonesia, terutama di Indonesia bagian Timur (NTT). Temuan nekara perunggu sebagai wadah kubur di Plawangan ini mempunyai keunikan yang jarang ditemui di seluruh Indonesia, bahkan di Asia Tenggara apalagi di dunia. Keistimewaannya, kubur nekara ini ditemukan dalam suatu penggalian (ekskavasi) secara sistematis yang dilakukan oleh Pusat Penelitian Arkeologi Nasional yang sudah berlangsung tahun 1977-1990. Jadi dapat dipastikan kubur nekara ini merupakan satu-satunya temuan data yang masih "insitu" dan sangat menarik perhatian para 

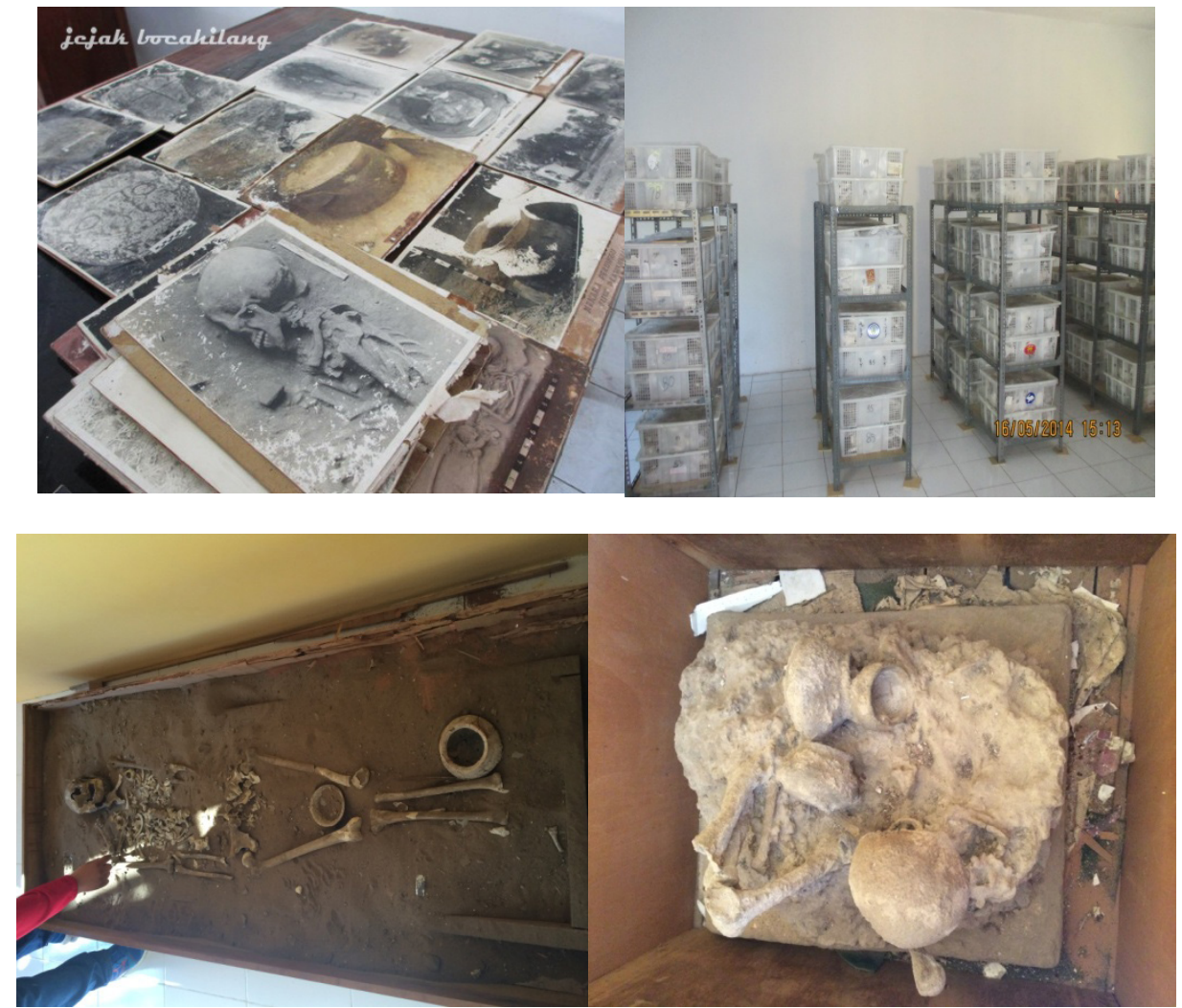

Gambar 7. Kolesi Foto Temuan Situs Plawangan

ahli, khususnya dalam bidang kepurbakalaan. "Dunia arkeologi" pun mencuat dan menjadi bahan perbincangan hangat di media masa pada waktu itu.

Nekara perunggu temuan di Situs Plawangan tersebut ternyata merupakan suatu wadah kubur untuk anak-anak. Di dalam nekara tersebut ditemukan rangka anak-anak yang sudah hancur dan berumur antara 8-10 tahun. Di bawah nekara ditemukan lagi satu rangka anak-anak yang lebih muda usianya, yaitu sekitar 4-6 tahun dalam keadaan tertindih oleh nekara dan temuk di bagian kepalanya. Mengapa ada dua rangka anak-anak yang umumnya hampir sebagai dikuburkan dalam nekara perunggu di Plawangan, hal ini masih menjadi tanda tanya dan teka-teki yang belum terpecahkan oleh para ahli prasejarah sampai saat ini. Ada suatu pendapat menyatakan bahwa rangka anak-anak yang berada di dalam nekara tersebut diduga adalah anak dari salah seorang tokoh masyarakat yang dihormati, sedangkan rangka anak-anak yang terletak di bawah/tertindih oleh nekara adalah pengikut setia atau teman akrab bermainnya yang sengaja dibunuh untuk menemani perjalanan tuannya ke alam baka.

Menurut kepercayaan pada masa prasejarah, seorang tokoh penting dalam masyarakat, seperti misalnya kepala suku, mempunyai pengaruh yang sangat kuat, dihormati dan disegani. Jika ia meninggal dunia, maka dalam penguburannya akan disertakan beberapa bekal kubur yang berharga atau pengikut/pelayan setianya yang rela dibunuh atau dijadikan korban untuk mengikuti perjalanan arwah tuannya. Demikian halnya dengan nekara temuan sebagai kubur di Plawangan tersebut, menunjukkan suatu bukti bahwa paling tidak, orang (anak-anak) yang dikubur tersebut mempunyai status sosial yang tinggi karena nekara merupakan suatu benda yang amat langka dan tinggi nilainya waktu itu.

Situs Plawangan diperkirakan merupakan sebuah "necropolis" atau tempat penguburan dari abad pertama masehi. Dari penggalian di situs itu, menunjukkan manusia Plawangan pada 2000 tahun silam me- 

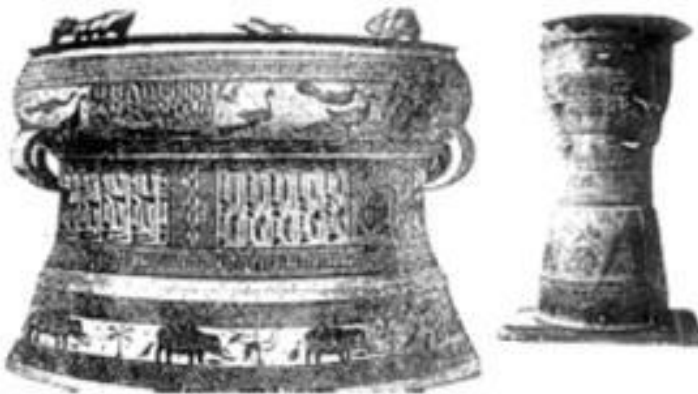

Gambar 8. Foto Nekara temuan Situs Plawangan

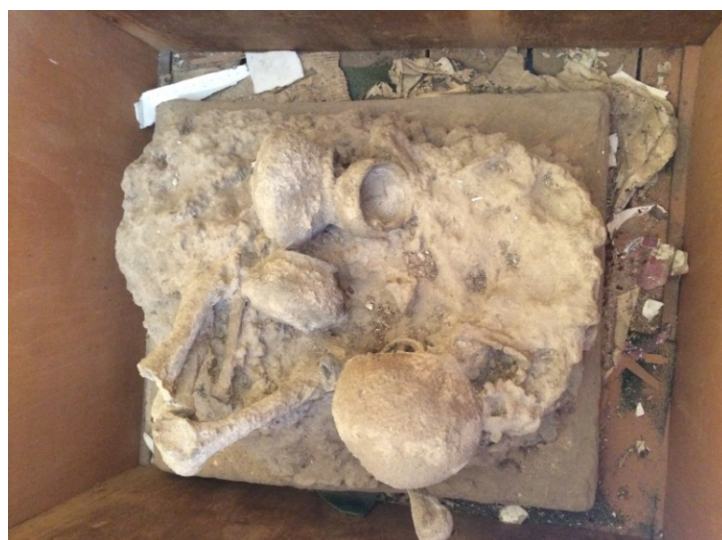

Gambar 9. Temuan Rangka Anak Situs Plawangan

miliki cara penguburan yang terbilang maju pada zamannya. Tubuh manusia dimasukkan dalam tempayan dan dikubur dalam tanah disertai dengan bekal kubur, seperti manikmanik, periuk, dan kendi. Nekara Perunggu Bahkan, di tempat ini ada satu temuan langka yang tidak ditemukan di situs lainnya yang berasal pada awal masehi. "Yaitu penemuan manusia yang dikubur dalam nekara perunggu. Hal ini membuat peneliti kebingungan, karena penemuan nekara perunggu tidak pernah ditemukan di tempat lain. Penemuan ini juga menunjukkan tingginya budaya manusia Terjan pada awal masehi," kata bapak tiga anak ini. Terbungkus Kerang Junaedi menguraikan, berbeda dengan situs lainnya, fosil dan berbagai ornamen yang ditemukan peneliti di situs Plawangan terbilang lebih kaya dan utuh. "Ini karena fosil dan bendabenda itu terbungkus kerang, sehingga fosil itu tidak mudah rusak dimakan waktu," katanya.

Mengingat kekayaan yang ada, pada 1980-an Balai Arkeologi sempat menawarkan kepada Pemkab untuk menjadikan situs Plawangan sebagai museum alam purbakala. Namun, Pemkab yang kala itu di bawah kepemimpinan Bupati Suratman tidak menanggapi tawaran itu. Karena tidak ada persetujuan dari Pemkab, Balai Arkeologi akhirnya hanya membeli sebidang tanah yang dipergunakan untuk membangun gedung penyimpan benda-benda temuan penggalian. Hingga tahun ini, ribuan fosil dan benda temuan yang tersimpan di gedung yang mulai rusak itu banyak yang belum dianalisis. Adapun situs penggalian sekarang sudah berdiri bangunan rumah penduduk dan Puskesmas III Kragan.

Situs Plawangan bahkan kebanyakan dari benda-benda yang ditemukan mengalami kerusakan, kerusakan tersebut banyak terjadi karena terabaikannya perawatan oleh benda-benda Cagar Budaya Situs Plawangan tersebut dan juga rusak karena memang dalam proses penggalian Situs Pawangan yang pernah dilakukan dahulu.

Indonesia kebudayaan sangat di hargai akan keberadaannya, oleh karena itu Pemerintah Kabupaten Rembang yang disini kewenangan Satuan Perangkat Daerah yaitu Dinas Kebudayaan, Pariwisata, Pemuda, dan Olahraga melakukan upaya untuk mencegah kerusakan benda - benda Cagar Budaya Situs Plawangan tidak mengalami kerusakan lebih lanjut dan melakukan pelestarian Situs Plawangan tersebut. Hal tersebut di akui juga oleh Junaidi penjaga dan sekaligus mengikuti langsung penggalian Situs Plawangan (Wawancara, 16/5/ 2014):

"Memang benda-benda Situs Plawangan banyak mengalami kerusakan, hal ini disebabkan karena Dinas Kebudayaan, Pariwisata, Pemuda, dan Olahraga kurang memperhatikan Situs Plawangan, dan disini saja saya digaji oleh BPCB. Kabupaten Rembang disin juga belum mempunyai tim ahli dalam melakukan pelestarian, tim ahli pun itu dari BPCB yang melakukan pelestariannya pun jarang dikarenakan jarak BPCB dengan Situs Plawangan jauh. Penjaga Situs Plawangan disini saya juga bekerja sen- 


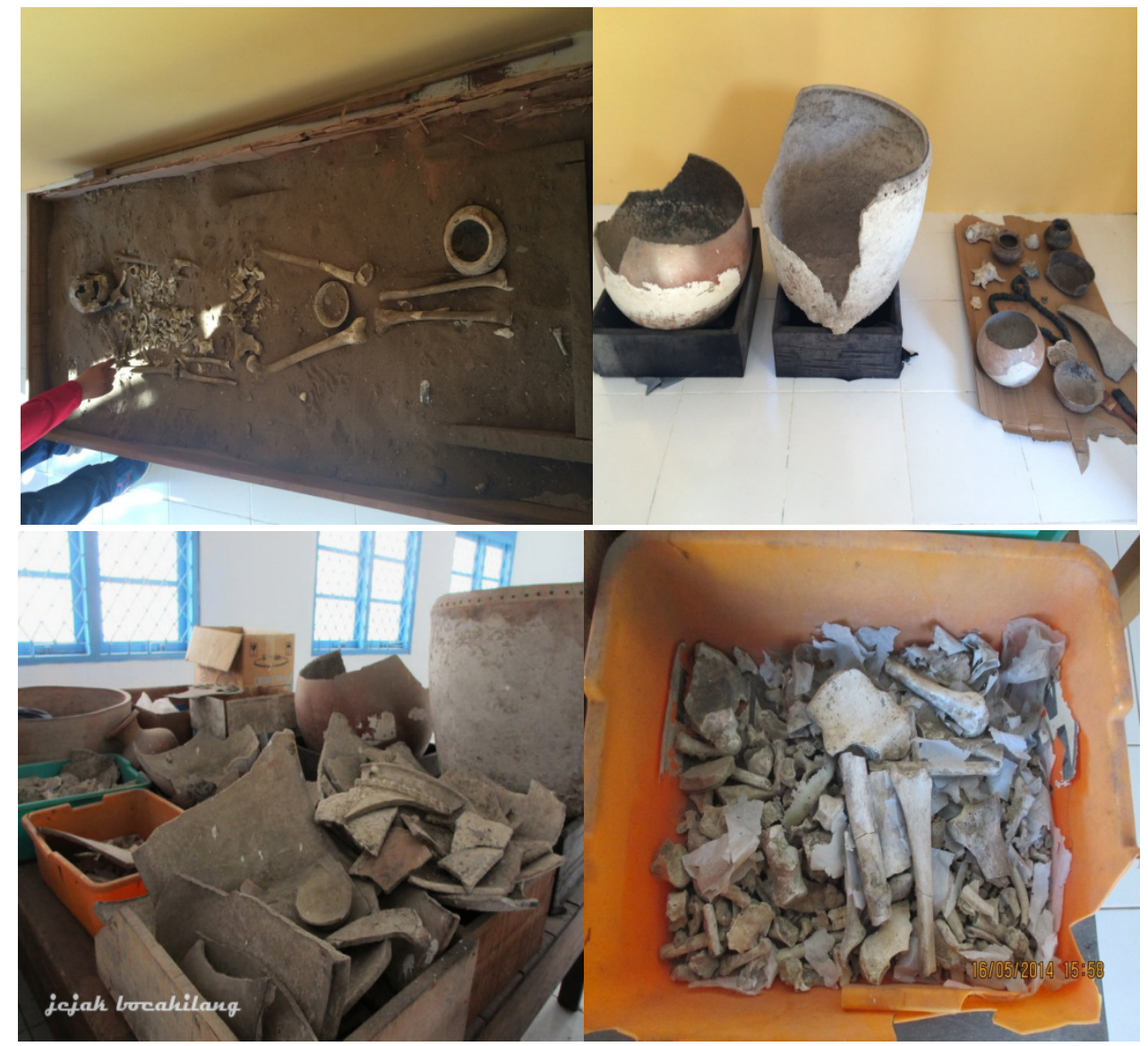

Gambar 10. Koleksi benda Situs Plawangan yang rusak dan terabaikan

diri, tentu saja dalam penjagaan Situs gan yaitu tentang kerusakan benda-benda Plawangan sangat kurang maksimal, Cagar Budaya, yaitu ditemui juga jika sisa ditambah dengan kondisi masyarakat penggalian tersebut ditemukan oleh orang Situs Plawangan tidak peduli dengan ataupun pecahan-pecahan yang sering dikeberadaan Situs Plawangan". temukan oleh masyarakat disalah gunakan dengan penemuan-penemuan benda-benda

Data tersebut bermakna bahwa peran Cagar budaya tersebut tidak dilaporkan lebih Dinas Kebudayaan, Pariwisata, Pemuda, dan lanjut ke Dinas Kebudayan, Pariwisata, PeOlahraga Kabupaten Rembang dalam me- muda, dan Olahraga Kabupaten Rembang, lestarikan Situs Plawangan kurang maksimal, dengan merujuk teori Jeremy Rifkyn yang dimerngingat juga dalam peran Dinas Kebuda- kutip dari buku Joost Smiers mernghubungyaan, Pariwisata, Pemuda, dan Olahraga Ka- kan budaya dan ekologi mengungkapkan bupaten Rembang juga belum mempunyai (Dinas Kebudayaa, Pariwisata, Pemuda dan tenaga ahli pelestarian di Siotus Plawangan.

Perhatian Pemerintah Kabupaten Rembang sangatlah dibutuhkan berhubung Situs Plawangan adalah masih wilayah dari Kabupaten Rembang, dan seharusnya Dinas Kebudayaan, Pariwisata, Pemuda, dan Olahraga harus mempunyai tim ahli dalam melakukan Situs Plawangan dan bertindak langsung dalam melakukan pelestarian Situs Plawangan. Selain yang ditemukan dalam Situs PlawanOlahraga, 2013):.

"Seperti alam, budaya dapat ditambang hingga habis terpakai. Jika budaya dieksploitasi secara berlebihan dan dihambur-hamburkan, pasar - pasar di dunia beresiko kehilangan ayam bertelur emasnya. Dengan demikian keanekaragaman budaya sama halnya dengan keanekaragaman hayati. Bila seluruh keanekaragaman budaya 
yang kaya dari pengalaman - pen- tanggung jawab Kabupaten Rembang, Situs galaman manusia di seluruh penjuru Plawangan yang terletak di Desa Plawangan, dunia dieksploitasi demi keuntungan Kecamatan Kragan 35 km dari kota Rembang komersial jangka pendek dan tidak di- ke timur jurusan Surabaya. Luas 0,5 km (miperkenankan untuk berdaur ulang dan lik Dinas Purbakala), yang terdapat peningdilengkapi kembali, ekonomi akan ke- galan sejarah berupa kerangka manusia yang hilangan telaga luas pengalaman ma- diperkirakan hidup pada zaman logam awal nusia yang merupakan bahan produksi (Paleomatalik). Pada tahun 1977 telah ditekebudayaan". mukan kerangka manusia, cara penguburan mayat dengan sikap duduk dalam belanga,

Penjelasan teori diatas sangatlah jelas bahwa keaneragaman budaya sangat merugikan Bangsa kita jika hanya dimanfaatkan dengan mengambil keuntungan jangka pendek, dimanfaatkan dengan merugikan $\mathrm{Ne}$ gara bahwa Cagar Budaya sangatlah penting keberadaannya karena itu adalah bagian dari sejarah Negara Indonesia dan bisa menjadikan pendidikan sejarah berkembang. Cagar Budaya tidak bisa didaur ulang untuk itulah sangat dirugikan Negara kita apabila bendabenda Cagar Budaya demi keuntungan komersil jangka pendek.

\section{c. Pelestarian Situs Cagar Budaya Pla- wangan Berdasarkan Undang - Un- dang Cagar Budaya}

Pelestarian benda cagar budaya merupakan inspirasi bagi kelanjutan perjuangan kita dan menjauhkan terjadinya keterasingan sejarah yang dapat mengakibatkan kemiskinan budaya. Maka perlu ditumbuh kembangkan pernahaman tentang pelestarian benda cagar budaya, sehingga selalu diperhatikan keserasian, keseimbangan, dan kesinambungan antara aspek fisik dan aspek sosial budaya. Kedua aspek itu tidak dapat dipisahkan untuk mendukung upaya pelestarian benda cagar budaya. Bantuan dan dukungan masyarakat sangat diperlukan, karenapada hakekatnya pelestarian benda cagar budaya tersebut menjadi tanggung jawab kita. Untuk itulah sebagai bangsa yang besar dan berbudaya marilah kita lestarikan warisan kebudayaan masa lalu untuk kebesaran bangsa tercinta.

Kabupaten Rembang yang merupakan bagian dari Indonesia, maka wajib untuk menjaga, melindungi, dan melestarikan $\mathrm{Ca}$ gar Budaya yang ada di wilayah dan menjadi manik-manik, gerabah, benda-benda logam, keramik. Untuk menjaga keaslian dan tetap bertahan sampai lama agar generasi penerus bisa merasakan Situs Cagar Budaya Plawangan, maka dari itu harus dilestarikan dan dalam hal ini menjadi tanggung jawab Pemerintah Daerah Kabupaten Rembang.

Hasil penelitian yang dilakukan oleh penulis di Dinas Kebudayaa, Pariwisata, Pemuda, dan Olahraga, dan Situs Plawangan. Kemudian yang dikembangkan peneliti dengan hasil wawancara yang dilakukan kepada penjaga Situs Plawangan, Kepala Dinas Kebudayaan, Pariwisata, Pemuda, dan Olahraga Kabupaten Rembang, Kasi Jarahmuskala (Sejarah Museum dan Purbakala) Dinas Kebudayaan, Pariwisata, Pemuda, dan Olahraga Kabupaten Rembang, dan Ketua LSM MSI (Masyarakat Sejarawan Indonesia) Kabupaten Rembang.

Bagan diatas menjelaskan bahwa peran Dinas Kebudayaan, Pariwisata, Pemuda,dan Olahraga Kabupaten Rembang dalam melakukan pelestarian sangatlah kurang maksimal, karena peran Dinas Kebudayaan, Pariwisata, Pemuda,dan Olahraga Kabupaten Rembang tidak berperan langsung dalam melakukan pelestarian tersebut dan hanya mengawasi dan menerima informasi dari penjaga Situs Plawangan dan BPCB (Balai Pelestarian Cagar Budaya) jika terjadi kerusakan dan kehilangan. Peran yang sesungguhnya melakukan pelestarian Situs Cagar Budaya Plawangan secara langsung adalah BPCB (Balai Pelestarian Cagar Budaya), disini BPCB melakukan pelestarian dengan terjun langsung pada Situs Plawangan dan melakukan pengecekan pada Situs Plawangan dan BPCB memberikan tugas kepada tenaga ahli dalam melakukan pelestarian Situs Plawangan.

Hal tersebut diakui oleh Edi Winarno 


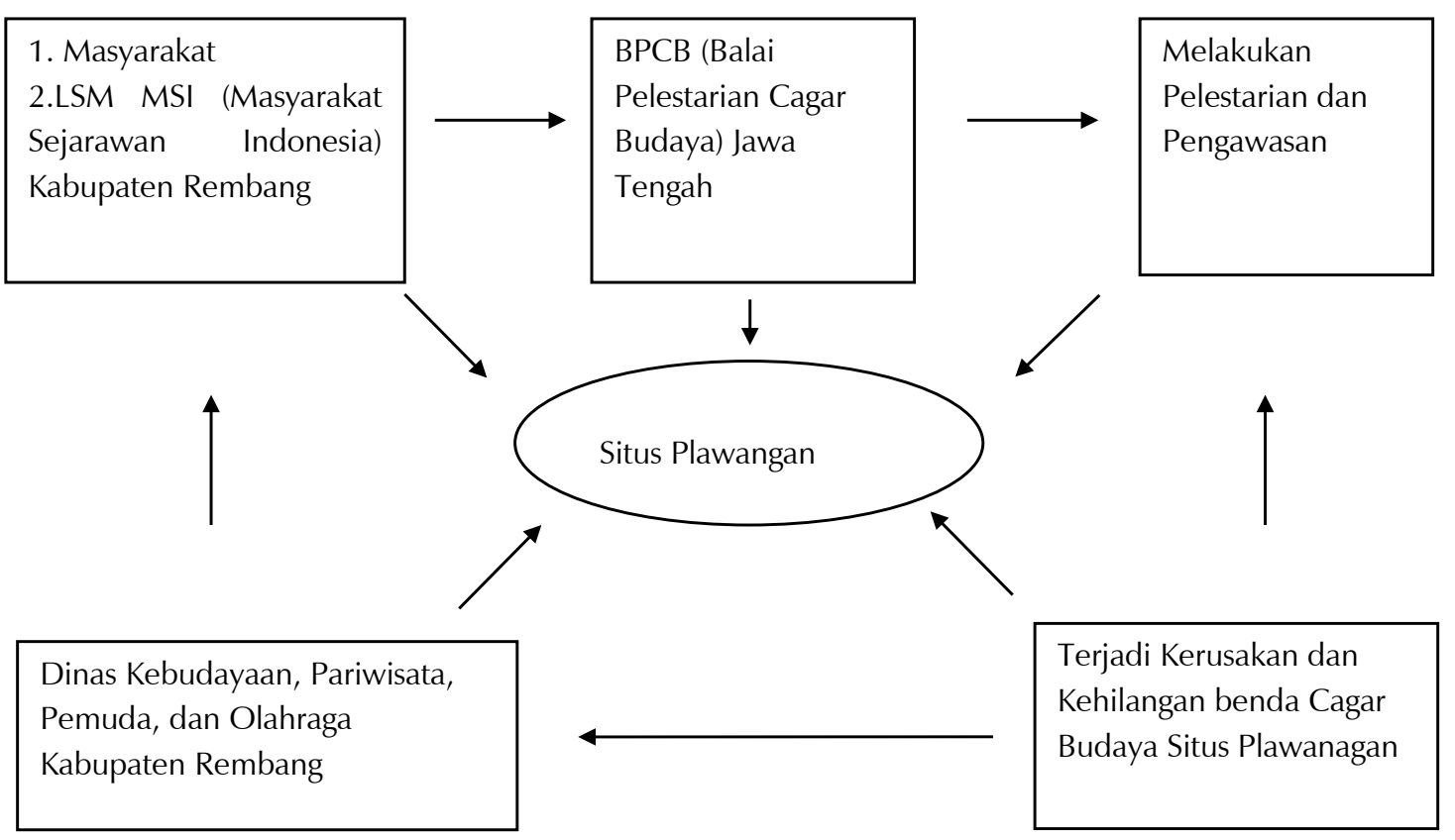

Bagan 2. Model Pelestarian Situs Cagar Budaya Plawangan Perspektif Dinas Kebudayaan,Pariwisata, Pemuda, dan Olahraga

Ketua LSM MSI (Masyarakat Sejarawan Indonesia) Kabupaten Rembang (Wawancara, 9/7/ 2014):

"Menurut saya peran Dinas Kebudayaan, Pariwisata, Pemuda, dan Olahraga Kabupaten Rembang sangatlah kurang maksimal, mengingat tugas Dinas Kebudayaan, Pariwisata, Pemuda, dan Olahraga Kabupaten Rembang selama ini tidak berperan langsung dalam melakukan pelestarian Situs Plawangan, dan sudah seharusnya Dinas Kebudayaan, Pariwisata, Pemuda, dan Olahraga Kabupaten Rembang harus mempunyai tenaga ahli dalam melakukan pelestarian Situs Plawangan, tentunya jika Dinas Kebudayaan, Pariwisata, Pemuda, dan Olahraga Kabupaten Rembang akan lebih maksimal dalam perannya melakukan pelestarian Siyus Plawangan. Seharusnya juga Dinas Kebudayaan, Pariwisata, Pemuda, dan Olahraga Kabupaten Rembang memberikan plangisasi Situs Plawangan supaya wisatawan bisa mengetahui tempat Situs Plawangan".

Hal tersebut di akui juga oleh Sunarto Kepala Dinas Kebudayaan, Pariwisata, Pemu- da, dan Olahraga Kabupaten Rembang (Wawancara, 6/7/ 2014):

"Memang benar bahwa Dinas Kebudayaan, Pariwisata, Pemuda, dan Olahraga Kabupaten Rembang hanya mengawasi Situs Plawangan dan Dinas Kebudayaan, Pariwisata, Pemuda, dan Olahraga Kabupaten Rembang hanya menerima laporan dari penjaga Situs Plawangan dan BPCB jika benda-benda Cagar Budaya mengalami kerusakan dan terjadi kehilangan tentunya peran Dinas Kebudayaan, Pariwisata, Pemuda, dan Olahraga Kabupaten Rembang disini akan menindaklanjuti laporan tersebut kepada pihak kepolisian. Jika ada anggaran APBD Kabupaten Rembang tentunya Dinas Kebudayaan, Pariwisata, Pemuda, dan Olahraga Kabupaten Rembang akan menyalurkannya ke Situs Plawangan untuk pelestarian dan perawatan Situs Plawangan".

Peneliti berpendapat bahwa dalam model pelestarian Situs Plawangan tersebut memang tidak optimal, mengingat disini Dinas Kebudayaan, Pariwisata, Pemuda, dan Olahraga Kabupaten Rembang diberi wewenang Kabupaten Rembang untuk melakukan pelestarian Situs Plawangan, tetapi dalam pe- 
lestarian Situs Plawangan peran Dinas Kebudayaan, Pariwisata, Pemuda, dan Olahraga Kabupaten Rembang tidak melakukan secara langsung dan hanya mengawasi saja.

\section{d. Hambatan Dinas Kebudayaan, Pari- wisata, Pemuda, dan Olahraga dalam Pelestarian Situs Cagar Budaya Plawa- ngan}

Dinas Kebudayaan, Pariwisata, Pemuda, dan Olahraga Kabupaten Rembang dalam melakukan tugas khususnya pada bidang kebudayaan tentunya akan menjumpai kendala atau hambatan maka untuk itu Dinas
Kebudayaan, Pemuda, dan Olahraga Kabupaten Rembang tidak ingin ada hambatan dalam melaksanakan tugas khususnya pada bidang kebudayaan, berikut adalah kendala Dinas Kebudayaan, Pariwisata, Pemuda, dan Olahraga Kabupaten Rembang dalam melakukan rancangan strategi SKPD di bidang kebudayaan (Renstra Dinbudoarpora Rembang 2010-2015).

Tabel 1 adalah kendala Dinas Kebudayaan, Pariwisata, Pemuda, dan Olahraga Kabupaten Rembang secara umum pada Bidang Kebudayaan yang tercantum pada Rencana Strategi SKPD tahun 2010 - 2015,

Tabel 1. Kendala Dinas Kebudayaan, Pariwisata, Pemuda, dan Olahraga Kabupaten Rembang Pada Bidang Kebudayaan.

\begin{tabular}{lll}
\hline No & \multicolumn{1}{c}{ Kendala } & \multicolumn{1}{c}{ Solusi ( Pemecahan ) } \\
\hline 1 & Kurangnya daya saing dalam & Pelestarian adat/tradisi/budaya daerah dengan men- \\
pengembangan nilai budaya & gadakan festival/lomba-lomba; \\
daerah & Bekerjasama dengan DKD mengenalkan/ mengem- \\
& bangkan/ melestarikan budaya daerah dengan men- \\
& gadakan pembinaan dan sosialisasi; \\
& Mengikutsertakan kelompok budaya pada festival/ \\
& pagelaran/event budaya di semua tingkatan;
\end{tabular}

2. Kurangnya aktivitas, kreativitas Bekerjasama dengan lembaga/ instansi terkait dalam dan kwalitas dalam pengelo- pelestarian nilai sejarah dan kekayaan budaya daerah laan potensi kekayaan budaya lainnya; daerah

Pemeliharaan terhadap kekayaan budaya daerah agar lebih eksis keberadaannya;

Peran serta dalam pembinaan/ pelatihan/ sosialisasi/ event lainnya di segala tingkatan;

3. Kurangnya sarana prasarana Mengadakan kerjasama dengan lembaga/ instansi kegiatan pengelolaan keraga- terkait $\mathrm{u} /$ mengusahakan sarpras kegiatan seni dan man budaya daerah budaya daerah;

Belum optimalnya pengelolaan Pemeliharan dan peningkatan kualitas serta fasilitas dan pembinaan terhadap tra- sarpras kegiatan yang ada;

disi, peninggalan sejarah dan Bekerjasama dengan lembaga/ instansi terkait dalam permuseuman pelestarian tadisi, peninggalan sejarah dan permuseuman;

4. Pemeliharan dan pelestarian terhadap tradisi, peninggalan sejarah dan permuseuman; Mengikutsertakan pengelola BCB dalam pembinaan/ pelatihan/ sosialisasi di Tk Provinsi;

Bekerjasama dengan Dinkebudpar Prov/ Dirjen Kebudpar Pusat mengadakan sosialisasi dan pembinaan terhadap penemuan kapal kuno dan benda-benda peninggalan sejarah serta permuseuman; 
dalam kendala tersebut salah satunya menjelaskan bahwa belum optimalnya pengelolaan dan pembinaan terhadap tradsi, peninggalan sejarah dan permuseuman, maka dalam hal ini berkaitan pada Situs Plawangan dengan kurang optimalnya pengelolaan dan pembinaan tersebut Dinas Kebudayaan, Pariwisata, Pemuda, dan Olahraga Kabupaten Rembang melakukan pelestarian Situs Plawangan.

Selain kendala yang dijelaskanpada table diatas Dinas Kebudayaan, Pariwisata, Pemuda, dan Olahraga Kabupaten Rembang juga mengalami kendala atau hambatan yangkhususnya Situs Plawangan yaitu dengan tidak adanya tenaga ahli dalam melakukan kegiatan langsung pelestarian Situs Plawangan, mengingat bahwa tenaga ahli sangatlah penting dala melakukan pelestarian Cagar Budaya,dan kendala dengan belum adanya Perda yang mengatur tentang Cagar Budaya yang sampai sekarang belum ada kepastian pada Dewan Perwakilan Daerah Kabupaten Rembang untuk menunggu pengesahan Perda tersebut.

Hal tersebut di akui juga oleh Siti Nuryati Kasi Jarahmuskala (Sejarah, Museum,dan Purbakala) Dinas Kebudayaan, Pariwisata, Pemuda, dan Olahraga Kabupaten Rembang (Wawancara, 6/6/ 2014).

Saat ini kendala Dinas Kebudayaan, Pariwisata, Pemuda, dan Olahraga Kabupaten Rembang dalam melakukan pelestarian Situs Plawangan adalah tidak adanya tenaga ahli dalam melakukan pelestarian dan Perda tentang Cagar Budaya yang sampai sekarang belum ada kejelasannya.

Sunarto Kepala Dinas Kebudayaan, Pariwisata, Pemuda, dan Olahraga Kabupaten Rembang juga mengakui hal tersebut (Wawancara, 6/6/ 2014).

Memang benar Kepala Dinas Kebudayaan, Pariwisata, Pemuda, dan Olahraga Kabupaten Rembang belum mempunyai tenaga ahli dalam melakukan pelestarian Cagar Budaya, tetapi kami sedang mengupayakan supaya Kepala Dinas Kebudayaan, Pariwisata, Pemuda, dan Olahraga Kabupaten Rembang mempunyai tenaga ahli dalam melakukan pelestarian Cagar Budaya, kaitannya dengan Situs Plawangan untuk sementara kami "menitipkan" Situs Plawangan kepada BPCB Jawa Tengah karena BPCB Jawa Tengah ada tenaga ahli dalam melakukan pelestarian tersebut.

Selain hal tersebut kita juga belum mempunyai Perda tentang Cagar Budaya yang belum ada kejelasan, tentunya jika Perda tentang Cagar Budaya sudah ada maka Cagar Budaya di Kabupetn Rembang khususnya Situs Plawangan akan lebih terlindungi dan lebih terjamin keamanannya.

Merujuk pada Undang - Undang No. 11 tahun 2010 tentang Cagar Budaya Pasal 85 adalah :

(1) Pemerintah, Pemerintah Daerah, dan setiap orang dapat memanfaatkan Cagar Budaya untuk kepentingan agama, sosial, pendidikan, ilmu pengetahuan, teknologi, kebudayaan, dan pariwisata.

(2) Pemerintah dan Pemerintah Daerah memfasilitasi pemanfaatan dan promosi Cagar Budaya yang dilakukan oleh setiap orang.

(3) Fasilitasi sebagaimana dimaksud pada ayat (2) berupa izin pemanfaatan, dukungan Tenaga Ahli Pelestarian, dukungan dana, dan/atau pelatihan.

(4) Promosi sebagaimana dimaksud pada ayat (2) dilakukan untuk memperkuat identitas budaya serta meningkatkan kualitas hidup dan pendapatan masyarakat.

Pada pasal tersebut sudah jelas bahwa Pemerintah Daerah harus memfasilitasi Tenaga Ahli Pelestarian untuk Cagar Budaya, maka sudah seharusnya Dinas Kebudayaan, Pariwisata, Pemuda, dan Olahraga Kabupaten Rembang sudah seharusnya mempunyai Tenaga Ahli Pelestarian dalam melakukan pelestarian Situs Cagar Budaya Plawangan. Dengan adanya Tenaga Ahli Pelestarian Cagar Budaya maka Dinas Kebudayaan, Pariwisata, Pemuda, dan Olahraga Kabupaten Rembang akan lebih maksimal dalam melakukan pelestarian Situs Plawangan. 


\section{e. Upaya Pelestarian Situs Cagar Bu- daya Plawangan}

Model pelestarian Situs Cagar Budaya Plawangan yang berperan penting dalam hal ini adalah Dinas Kebudayaan, Pariwisata, Pemuda, dan Olahraga. Hal terseburt juga diatur dalam Undang-Undang Nomor 11 tahun 2010 tentang Cagar Budaya yang mengatur tentang Tugas dan Wewenang, yang menyatakan sebagai berikut :

Pasal 95

(1)Pemerintah dan/atau Pemerintah Daerah mempunyai tugas melakukan Pelindungan, Pengembangan, dan Pemanfaatan Cagar Budaya.

(2) Pemerintah dan Pemerintah Daerah sesuai dengan tingkatannya mempunyai tugas:

a.mewujudkan, menumbuhkan, mengembangkan, serta meningkatkan kesadaran dan tanggung jawab akan hak dan kewajiban masyarakat dalam pengelolaan Cagar Budaya;

b. mengembangkan dan menerapkan kebijakan yang dapat menjamin terlindunginya dan termanfaatkannya Cagar Budaya;

c. menyelenggarakan penelitian dan pengembangan Cagar Budaya;

d. menyediakan informasi Cagar Budaya untuk masyarakat;

e. menyelenggarakan promosi Cagar Budaya;

f. memfasilitasi setiap orang dalam melaksanakan pemanfaatan dan promosi Cagar Budaya;

g. menyelenggarakan penanggulangan bencana dalam keadaan darurat untuk benda, bangunan, struktur, situs, dan kawasan yang telah dinyatakan sebagai Cagar Budaya serta memberikan dukungan terhadap daerah yang mengalami bencana;

h. melakukan pengawasan, pemantauan, dan evaluasi terhadap pelestarian warisan budaya; dan

i. mengalokasikan dana bagi kepentingan pelestarian Cagar Budaya.

Melanindaklanjuti Peraturan tersebut
Pemeruntah Kabupaten Rembang khususnya Dinas Kebudayaan, Pariwisata, Pemuda, dan Olahraga yang mempunyai wewenang dalam hal ini melestarikan, melindumgi Situs Plawangan membuat Rancangan Strategi Satuan Kerja Perangkat Daerah ( RENSTRA SKPD ) dalam Rancangan Strategi tersebut sebagian menjelaskan pelestarian Situs Plawangan dan usaha Dinas Kebudayaan, Pariwisata, Pemuda, dan Olahraga untuk lebih mendekatkan kepada masyarakat dan khususnya bagi wisatawan yang berkunjung ke Kabupaten Rembang, kemudian Dinas Kebudayaan, Pariwisata, Pemuda dan Olahraga juga membuat paket wisata dari paket wisata tersebut wisatawan juga diarahkan ke Situs Plawangan.

Bagan 3 di atas menunjukkan bahwa Dinas Kebudayaan, Pariwisata, Pemuda dan Olahraga Kabupaten Rembang bukti bahwa sudah berupaya dalam melakukan pelestarian Situs Cagar Budaya Plawangan Kabupaten Rembang dan berusaha memperkenalkan kepada wisatawan untuk mengunjungi Situs Cagar Budaya Plawangan, dan bagan tersebut adalah bagian dari Rencana Strategi Satuan Perangkat Daerah yaitu Dinas Kebudayaan, Pariwisata, Pemuda, dan Olahraga.

Selain upaya dari Rencana Strategi Satuan Perangkat Daerah, Dinas Kebudayaan, Pariwisata, Pemuda dan Olahraga Kabupaten Rembang telah membuat rancangan Peraturan Daerah yang mengatur tentang Cagar Budaya, Rancangan Peraturan Daerah tersebut telah dibuat dan sudah di ajukan tinggal menunggu keputusan Dewan Perwakilan Rakyat Daerah Kabupaten Rembang. Rancangan Perda tersebut agar Cagar Budaya di Kabupaten tetap terlindungi dan pelestariannya terjamin.

Hal tersebut di akui juga oleh Siti Nuryati Kasi Jarahmuskala (Sejarah, Museum,dan Purbakala) Dinas Kebudayaan, Pariwisata, Pemuda, dan Olahraga Kabupaten Rembang (Wawancara, 6/6/ 2014).

Pelestarian Situs Plawangan disini kami mengupayakan untuk mempunyai tenaga ahli untuk melakukan pelestarian Situs Plawangan, sampai sekarang Dinas Kebudayaan, Pariwisata, Pemuda, dan Olahraga Kabupaten Rembang belum mempunyai tenaga ahli tentang 


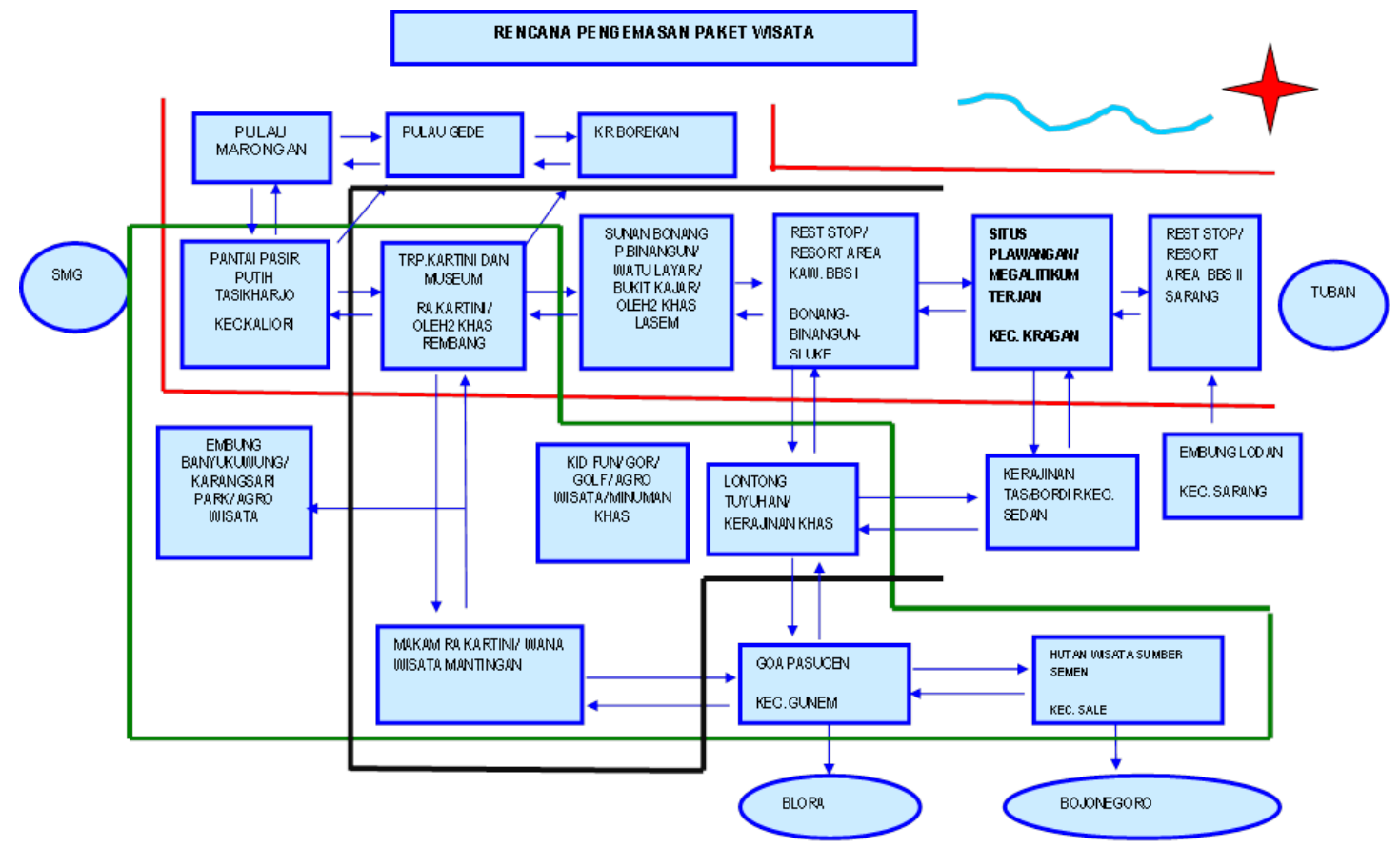

Bagan 3. Rencana Pengemasan Paket Wisata Dinas Kebudayaan, Pariwisata, Pemuda dan Olahraga Kabupaten Rembang

cagar budaya. Tentunya disini kami akan terus mengupayakan agar mempunyai tenaga ahli.

Selain itu kami sekarang juga sedang menupayakan Perda tentang Cagar Budaya, Perda tersebut sedang proses pengesahan. Agar keberadaan Cagar Budaya Kabupaten Rembang lebih terlindungi dan lebih terjamin keamannya dengan adanya Perda tersebut.

Hal tersebut di akui juga oleh Sunarto Kepala Dinas Kebudayaan, Pariwisata, Pemuda, dan Olahraga Kabupaten Rembang (Wawancara, 6/6/ 2014):

Memang benar Kepala Dinas Kebudayaan, Pariwisata, Pemuda, dan Olahraga Kabupaten Rembang belum mempunyai tenaga ahli dalam melakukan pelestarian Cagar Budaya, tetapi kami sedang mengupayakan supaya Kepala Dinas Kebudayaan, Pariwisata, Pemuda, dan Olahraga Kabupaten Rembang mempunyai tenaga ahli dalam melakukan pelestarian Cagar Budaya, kaitannya dengan Situs Plawangan untuk sementara kami "menitipkan" Situs Plawangan kepada BPCB Jawa Tengah karena BPCB Jawa Tengah ada tenaga ahli dalam melakukan pelestarian ter- sebut.

Selain itu juga kami mengupayakan Perda tentang Cagar Budaya untuk segera disahkan, dan Perda tersebut sedang dalam proses, tentunya saya sebagai Kepala Kepala Dinas Kebudayaan, Pariwisata, Pemuda, dan Olahraga Kabupaten Rembang akan terus mengupayakan hal tersebut agar segera mempunyai Perda yang mengatur tentang Cagar Budaya.

Wawancara tersebut diatas menjelaskan bahwa memang benar kinerja Dinas Kebudayaan, Pariwiwsata, Pemuda, dan Olahraga Kabupaten Rembang kurang akan tetapi disini Dinas Kebudayaan, Pariwiwsata, Pemuda, dan Olahraga Kabupaten Rembang sudah mengupayakan agar Situs Plawangan tersebut terselamatkan dari kerusakan dan bisa dilestarikan, untuk itu Situs Plawangan "dititipkan" oleh BPCB Jawa Tengah untuk kelestariannya. Dinas Kebudayaan, Pariwiwsata, Pemuda, dan Olahraga Kabupaten Rembang saat ini juga sedang mengupayakan Peraturan Daerah tentang Pengelolaan dan Pelestarian Cagar Budaya.

Peneliti mempunyai model yang me- 
nurut peneliti lebih efektif dan maksimal dalam melakukan proses pelestarian Situs Plawangan Kabupaten Rembang.

Bagan diatas adalah model pelestarian yang menurut peneliti lebih efektif, maksimal, kemudian model pelestarian kontruksi dari penulis juga menggunakan teori William N. Dunn proses komunikasi publik. Peran Dinas Kebudayaan, Pariwisata, Pemuda, dan Olahraga Kabupaten Rembang lebih terjun langsung dalam melakukan pelestarian Situs Plawangan dan akan lebih mengetahui langsung keadaan Situs Plawangan dan kemudian melakukan presentasi kebijakan yang terkait dengan pelestarian Situs Plawangan kepada mastarakat dan LSM yang terkait. Jadi Dinas Kebudayaan, Pariwisata, Pemuda, dan Olahraga Kabupaten Rembang tidak hanya mengawasi saja, tetapi harus mempunyai tenaga ahli dalam melakukan Situs Plawangan tersebut, kemudian Dinast Kebudayaan, Pariwisata, Pemuda, dan Olahraga Kabupaten Rembang bekerjasama dengan BPCB Jawa
Tengah untuk melakukan pelestarian dan BPCB Jawa Tengah juga mengawasi kinerja Dinas Kebudayaan, Pariwisata, Pemuda, dan Olahraga Kabupaten Rembang.

Masyarakat dan LSM MSI (Masyarakat Sejarawan Indonesia) Kabupaten Rembang juga ikut melakukan pelestarian dan mengawasi Situs Plawangan dan kemudian masyarakat dan LSM MSI Kabupaten Rembang memberikan laporan ke Dinas Kebudayaan, Pariwisata, Pemuda, dan Olahraga Kabupaten Rembang jika terjadi kerusakan, kehilangan, bahkan penemuan baru Sirus Plawangan. Jika terjadi kerusakan ataupun kehilangan pada benda-benda Situs Plawangan kemudian dilakukan rehabilitasi dan kemudian semua komponen, yaitu : Dinas Kebudayaan, Pariwisata, Pemuda, dan Olahraga Kabupaten Rembang, BPCB Jawa Tengah, LSM MSI (Masyarakat Sejarawan Indonesia) Kabupaten Rembang, Masyarakat bersinergi melakukan pelestarian Situs Plawangan.

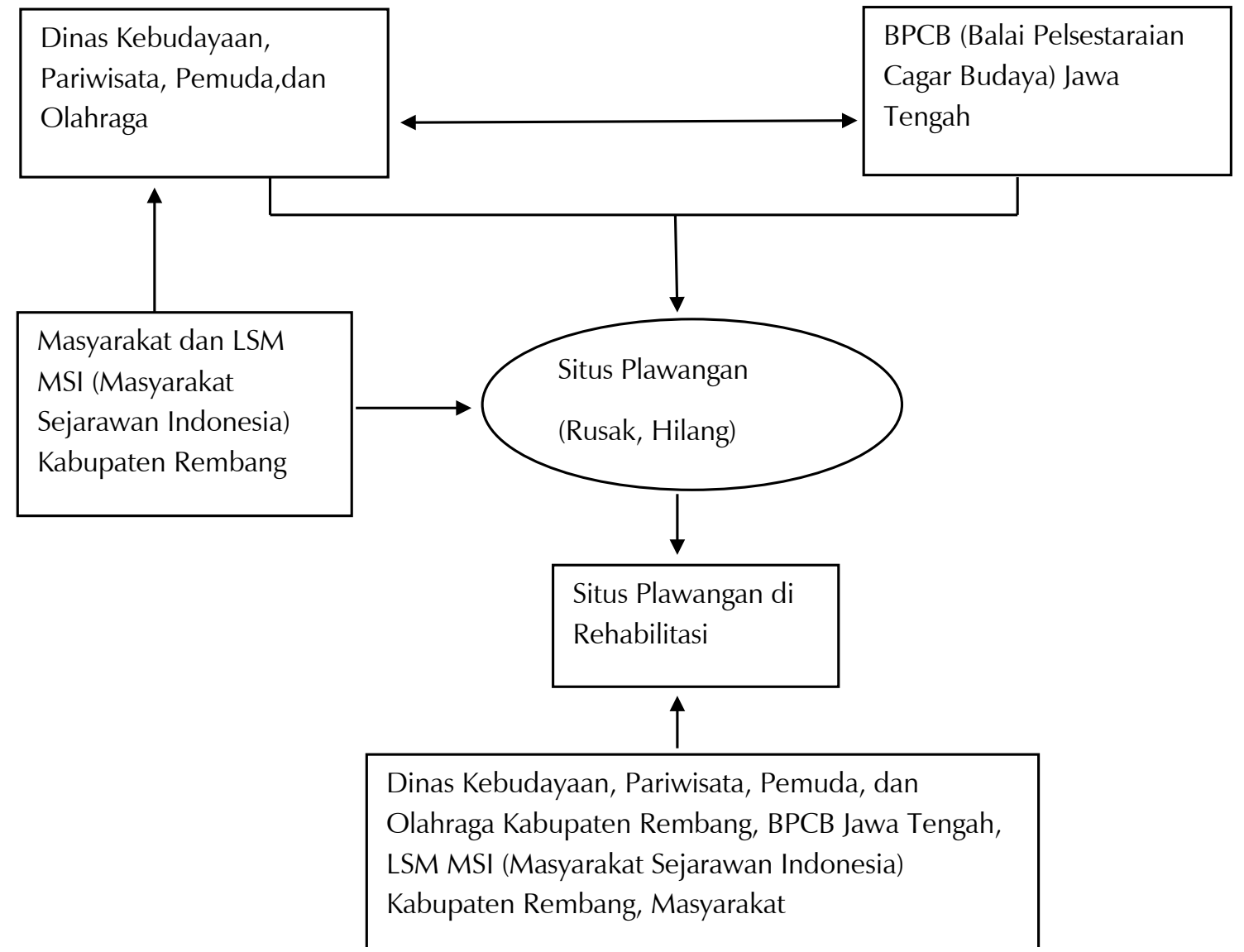

Bagan 4. Ragaan model pelestarian Situs Plawangan hasil analisis penelitian oleh penulis 


\section{Simpulan}

Hasil penelitian yang dilakukan pada Situs Plawangan dan Dinas Kebudayaan, Parwiwsata, Pemuda, dan Olahraga Kabupaten Rembang di simpulkan. Pertama, kebijakan Pemerintah Daerah Kabupaten Rembang dalam pelestarian Situs Plawangan adalah dalam menjalankan amanat Undang-Undang Nomor 11 tahun 2010 tentang Cagar budaya, karena Kabupaten Rembang sampai saat ini belum mempunyai Perda yang mengatur mengenai Cagar Budaya. Selain itu, secara sosiologis, perhatian masyarakat terhadap Situs Plawangan kurang antusias dan kurang memperhatikan untuk melakukan pelestarian Situs Plawangan. Oleh sebab itu, model Pelestarian Situs Cagar Budaya Plawangan yang relevan menggunakan instrumen Perda, agar perlindungan hukum terjamin, pelestariannya jelas, dan anggaran dananya juga jelas.

\section{Daftar Pustaka}

Antonius, Mikahel. 2013. "Studi tentang Pelestarian Cagar Budaya Masyarakat Dayak Bulusu di Desa Terindak Kecamatan Sekatak Kabupaten Bulungan". eJournal Ilmu Pemerintahan Volume 1 Nomor 3. Unmul.

Dinas Kebudayaan, Pariwisata, Pemuda, dan Olahraga. 2013. Profil Kebudayaan, Pariwisata, Pemuda dan Olahraga Kabupaten Rembang. Rembang.
Dunn, William N. 2003. Pengantar Analisis Kebijakan Publik. Yogyakarta : Gadjah Mada University Press.

Koentjaraningrat. 2002. Kebudayaan Mentalitas dan Pembangunan. Jakarta : Gramedi.

Miles, Mattew B dan A. Michael Huberman. 1992. Analisis Data Kulaitatif. Jakarta : UI-Press.

Moleong, Lexy J. 2013. Metodologi Penelitian Kualitatif. Bandung : PT Remaja Rosdakarya.

Soekanto, Soerjono. 1982. Pengantar Penelitian Hukum. Jakarta : UI-Press.

Soekmono. 2012 Pengantar Sejarah Kebudayaan Indonesia 1. Yogyakarta : Anggota IKAPI.

Sukendar, Haris dan Rokhus Due Awe. 1982. Laporan Penelitian Terjan dan Plawangan Jawa Tengah Tahap I dan II. PT Sumber Bahagia : Jakarta.

Waluyo, Bambang. 2002. Penelitian Hukum Dalam Praktek. Jakarta : Sinar Grafika.

Wirastari, Volare Amanda dan Rimadewi Suprihardjo. 2012. "Pelestarian Kawasan Budaya Berbasis Partisipasi Masyarakat (Studi Kasus: Kawasan Cagar Budaya Bubutan, Surabaya)". Jurnal Teknik Pomits Volume 1 Nomor 1. Surabaya : Institut Teknologi Sepuluh November (ITS).

\section{Peraturan Perundang-undangan :}

Undang-undang RI Nomor 11 Tahun 2010 Tentang Cagar budaya.

Perda Provinsi Jawa Tengah Nomor 10 Tahun 2013 Tentang Pelestarian dan Pengelolaan Cagar Budaya Provinsi Jawa Tengah.

Rancangan Peraturan Daerah Kabupaten Rembang Tentang Pengelolaan dan Pelestarian Cagar Budaya 